\title{
Agricultural Drought Assessment Based on Multiple Soil Moisture Products
}

Jongjin Baik

Sungkyunkwan University

Muhammad Zohaib

Sungkyunkwan University

Ungtae Kim

Cleveland State University, u.kim@csuohio.edu

Muhammad Aadil

Sungkyunkwan University

Minha Choi

Sungkyunkwan University

Follow this and additional works at: https://engagedscholarship.csuohio.edu/encee_facpub

Part of the Civil and Environmental Engineering Commons

How does access to this work benefit you? Let us know!

Publisher's Statement

https://doi.org/10.1016/j.jaridenv.2019.04.007

\section{Recommended Citation}

Baik, Jongjin; Zohaib, Muhammad; Kim, Ungtae; Aadil, Muhammad; and Choi, Minha, "Agricultural Drought Assessment Based on Multiple Soil Moisture Products" (2019). Civil and Environmental Engineering Faculty Publications. 129.

https://engagedscholarship.csuohio.edu/encee_facpub/129

This Article is brought to you for free and open access by the Civil and Environmental Engineering at EngagedScholarship@CSU. It has been accepted for inclusion in Civil and Environmental Engineering Faculty Publications by an authorized administrator of EngagedScholarship@CSU. For more information, please contact library.es@csuohio.edu. 


\title{
Agricultural drought assessment based on multiple soil moisture products
}

\author{
Jongjin Baik, Muhammad Zohaib, Ungtae Kim, Muhammad Aadil, Minha Choi
}

A R T I C L E IN F O

Keywords:

Agricultural drought

Soil moisture

ASCAT

AMSR2

ERA-Interim

AWRA-L

\begin{abstract}
A B S T R A C T
In this study, we evaluated three soil moisture (SM) products (Advanced Microwave Scanning Radiometer-2 [AMSR2], Advanced SCATterometer [ASCAT], and European Reanalysis Interim [ERA-interim]) across Australia in four climate zones by comparing against the Australian Water Resources Assessment-Landscape (AWRA-L) SM products from July 2012 to June 2017. The ASCAT SM indicated better performance than other SM products over Australia. To evaluate the applicability and reliability for monitoring agricultural drought, an agricultural drought index, the Soil Water Deficit Index, was estimated from three SM products and compared with three commonly-used drought indices (atmospheric water deficit [AWD], Evaporative Stress Index, and Reconnaissance Drought Index). Volumetric contingency tables were compiled to quantitatively assess the performance of agricultural drought detection using various SM products compared with the AWD. All products had reliable drought detection capability over Australia based on the results of temporal evolution and contingency tables with a mean volumetric hit index of $0.700,0.728$, and 0.787 for AMSR2, ASCAT, and ERAinterim, respectively. The slight incapability of drought detection capability of SWDI in tropical region was low due to the variation in persistence times of moisture in the atmosphere and soil. Except arid zone, in all climate zones, the reliability of SM products for drought detection followed the following order ASCAT > ERAinterim > AMSR2.
\end{abstract}

\section{Introduction}

Droughts are recurring extreme climatic phenomena that affect human lives in terms of water scarcity and crop production (Mishra and Singh, 2010; Dai, 2013). Generally, drought is described as low precipitation (P) over a long period, eventually reducing soil water availability for plants (AghaKouchak et al., 2015). Droughts are mainly categorized into four types: agricultural, hydrological, meteorological, and socio-economic (Mishra and Singh, 2010). Various hydrological variables have been adopted to define distinctive drought indices, such as the Palmer Drought Severity Index (Palmer, 1965), Atmospheric Water Deficit (AWD; Purcell et al., 2003), Standardized Precipitation Index (McKee et al., 1993), Standardized Precipitation Evapotranspiration Index (Vicente-Serrano et al., 2010), Scaled Drought Condition Index (Rhee et al., 2010), Crop Moisture Index (Palmer, 1968), Evaporative Stress Index (ESI; Anderson et al., 2007, 2011), Reconnaissance Drought Index (RDI; Tsakiris et al., 2007), and Multivariate Standardized Drought Index (Hao and AghaKouchak, 2013).
These indices are based on P, evapotranspiration (ET), and vegetation, which are related to hydrological and meteorological droughts. However, Mozny et al. (2012) found that low P affects the physical properties of soil by creating a crust that decreases infiltration and weakens the interaction between soil and atmosphere during dry periods. Therefore, the abovementioned indices are not suitable measures for assessing agricultural drought that is characterized by soil water availability and associated soil properties and plays a critical role in crop production.

Australia is the driest continent on earth and suffers from persistent drought events. At the start of the 21st century, a long uninterrupted drought (called the Millennium drought) hit Australia and lasted for most of the decade (2001-2009), severely damaging river ecosystems and dryland agriculture (Chiew et al., 2014; Park et al., 2019). Previous studies on drought in Australia mainly focused on meteorological drought characterized as below-average rainfall (Tsakiris and Vangelis, 2005; Rahmat et al., 2015). However, to assess the impact of drought on agricultural productivity and crop growth, studying agricultural 
drought is very important. To the best of our knowledge, studies on agricultural drought in Australia remain scarce. Thus, in this study, we evaluated the potential applicability of monitoring agricultural drought in Australia. Agricultural drought occurs when a deficiency in soil moisture (SM) $\left[\mathrm{L}^{3} \mathrm{~L}^{-3}\right]$ starts adversely affecting crop growth and ultimately reducing crop yield (Panu and Sharma, 2002). Several agricultural drought indices have been developed, such as the Soil Moisture Deficit Index (Narasimhan and Srinivasan, 2005), Soil Wetness Deficit Index (Keshavarz et al., 2014), Agricultural Reference Index for Drought (Woli et al., 2012), and Soil Moisture Drought Severity (Qin et al., 2015). These agricultural drought indices are either based on vegetation indices or SM calculated from water balances or hydrological modeling. Moreover, SM time-series from satellite remote sensing were directly used for defining or assessing a gricultural drought events in the Little River Experimental Watershed in the state of Georgia, USA (Choi et al., 2013) and the Horn of Africa region (Ambaw, 2013). Recently, Martínez-Fernández et al. (2015) proposed an agricultural drought index, the Soil Water Drought Index (SWDI), which accurately reflects agricultural drought by explicitly including soil and water properties. Primary features of agricultural drought identification, such as the beginning, ending, duration, and severity, can be efficiently determined using SWDI (Martínez-Fernández et al., 2016).

One of the important parameters of SWDI is SM, which plays a critical role in the hydrological cycle between the land surface and atmosphere (Owe et al., 2001; Bateni and Entekhabi, 2012). The Global Climate Observing System recognized SM as an "Essential Climate Variable," signifying its influence o n P, E T, i nfiltration, an d runoff (Brocca et al., 2011). SM products are frequently used to predict hydrological extremes such as floods (Massari et al., 2018) and droughts (Martínez-Fernández et al., 2015). Similarly, they have been used to predict landslides (Brocca et al., 2012) and dust outbreaks (Kim et al., 2017). SM products are generally obtained by three different methods: in situ measurements, satellite remote sensing, and hydrological modeling (Entekhabi et al., 2010; Kerr et al., 2010). Many remote sensing platforms and hydrological models have been developed to provide SM on diverse spatial and temporal scales (Wagner et al., 2012; Dorigo et al., 2015). The most prominent currently operating missions are Soil Moisture Active and Passive (SMAP), Soil Moisture and Ocean Salinity (SMOS), Advanced SCATterometer (ASCAT), Advanced Microwave Scanning Radiometer-2 (AMSR2), European Reanalysis Interim (ERAinterim), and Global Land Data Assimilation System (GLDAS) (Rodell et al., 2004; Entekhabi et al., 2010; Kerr et al., 2010; Dee et al., 2011; Wagner et al., 2013; Parinussa et al., 2015; Kim et al., 2018). Depending on different $\mathrm{l}$ and $\mathrm{c}$ overs a nd $\mathrm{c}$ limate $\mathrm{z}$ ones, S M products computed from various satellite missions and models yield dissimilar results compared to reference datasets (Kim et al., 2017; Albergel et al., 2013; Brocca et al., 2011).

Considering the uncertainty of various SM products in different land uses and climate conditions, the distribution of agricultural drought from multiple SM products in various climate zones across Australia was evaluated and compared for the first time in this study. SWDI from various SM products was calculated to assess agricultural drought and compared with AWD across Australia. We used two satellite-based (AMSR2 and ASCAT, passive and active sensors, respectively) and one modeled (ERA-interim) SM product to estimate SWDI. Although, pointscale validation of these products in Australia has been carried out several times (Su et al., 2013; Parinussa et al., 2015; Balsamo et al., 2015; Holgate et al., 2016). However, uneven distribution of pointbased SM observations across the various climate zones make the validation biased.

In this study, AWRA-L, which is the SM product of the Bureau of Meteorology (BoM; Vaze et al., 2013), was used as the reference SM data to compare the performance of other SM products on a grid based over Australia from July 2012 to June 2017. The AWRA-L was used as a reference dataset because of its reliability, as reported by Renzullo et al. (2014). They evaluated AWRA-L SM products against in situ networks of Oznet and cosmic-rays (CosmOz) in southeast Australia and found reliable correlations $(0.68-0.73)$ with surface and sub-surface SM. Similarly, Holgate et al. (2016) compared various remotely sensed and modeled SM products with in situ measurements from OzNet, OzFlux, and CosmOz (including AWRA-L) and found that AWRA-L was better at simulating temporal anomalies of in-situ, with a correlation range of $0.58-0.89$. To assess the severity and distribution of agricultural drought over Australia, SWDI was computed using all three SM products and compared with a reference drought index, i.e., the AWD obtained from meteorological data from the BoM. The primary objectives of this study are as follows: 1 ) to compare SM products (i.e., AMSR2, ASCAT, and ERA-interim) against the AWRA-L SM product, 2) to calculate weekly SWDI from various SM products across four climate zones in Australia and evaluate them by comparing with the commonly used drought indices, such as AWD, ESI, and $\mathrm{RDI}_{\mathrm{st}}$ and 3) to assess the agricultural drought detection skills of various SM products by calculating volumetric contingency table.

\section{Study area and data}

\subsection{Study area}

Australia lies between $10^{\circ}$ and $44^{\circ} \mathrm{S}$ and $112^{\circ}-154^{\circ} \mathrm{E}$ with an area of $7,692,024 \mathrm{~km}^{2}$ consisting of various ecological and climatic characteristics (Horridge et al., 2005). Australia has witnessed lengthy and severe droughts in the past and suffered the "Millennium Drought" from 2001 to 2009 (van Dijk et al., 2013). These droughts brought huge losses to the Australian economy and a humanitarian crisis (Van Dijk et al., 2013). Because of its geographic location and rainfall patterns, Australia is continuously affected by droughts that remain a major concern of hydrologic scientists and researchers (AghaKouchak et al., 2014; Kiem et al., 2016). To evaluate the distribution and variation of agricultural drought in various climate regions, the study area was divided into four climate zones according to the Köppen Geiger Climate Classification. The climate classification proposed by Peel et al. (2007) and Cho et al. (2017) for Australia was followed in this study. This classification comprises tropical, arid, temperate dry summer (DS), and temperate non-dry summer (NDS) climates (Fig. 1).

\subsection{AWRA-L SM product}

AWRA-L model (http://www.bom.gov.au/water/landscape/) developed by BoM and Commonwealth Scientific and Industrial Research Organization provides essential water resource information for Australia, including daily SM, P, and ET at a spatial resolution of $0.05^{\circ} \times 0.05^{\circ}$ (Johnston et al., 2003; Vaze et al., 2013; Viney et al., 2014). The input forcing datasets of AWRA-L includes Australian Water
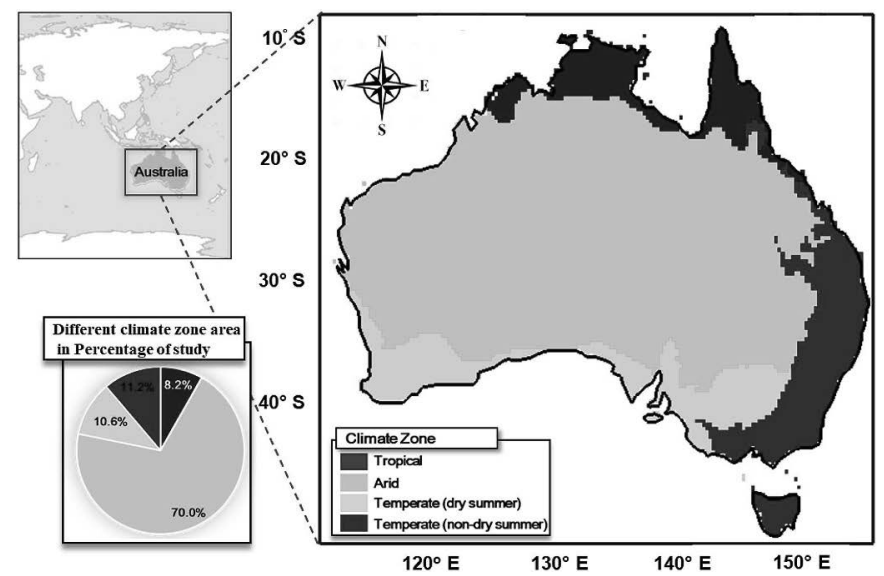

Fig. 1. Map of Australia and its four climate zones. 
Availability Project meteorological grids, which provided daily rainfall, minimum and maximum air temperature, and solar radiation. The SM products from AWRA-L are computed by water balance on each grid considering two hydrological response units (HRU s): shallow-rooted vegetation, which has access only to the two upper soil layers (i.e., the top layer $[0-10 \mathrm{~cm}]$ and shallow root zone layer $[10-100 \mathrm{~cm}])$, and deep-rooted vegetation, which also has access to a deep root zone layer $(100-600 \mathrm{~cm})$. Soil properties were obtained using pedotransfer functions in different layers (Johnston et al., 2003). Daily P products are calculated from more than 6,500 rain gauge stations installed by the BoM throughout Australia, while potential evapotranspiration (PET) is calculated using the equations of Penman (1948) (Jones et al., 2009). AWRA-L also provides the actual evapotranspiration (AET) products, which are misrepresented in major urban and irrigated croplands due to a lack of information about the impervious layer and irrigated crops in HRUs (Van Dijk and Bruijnzeel, 2001). In this study, the top layer SM, $\mathrm{P}, \mathrm{PET}$, and AET products from the AWRA-L model were used after upscaling to $0.25^{\circ} \times 0.25^{\circ}$ to match its spatial resolution to other products. The SM product from AWRA-L was used as a reference to compare the SM of AMSR2, ASCAT, and ERA-interim, and P, AET, and PET were used to estiamte the other reference drought indices, such as AWD, The choice of AWRA-L SM as a reference for comparison of other SM products aligns with our research goal, the evaluation of SWDI based on respective SM products in different c limate $\mathrm{z}$ ones. SM observations in Australia have limited spatial coverage across various climate zones. Most hydrological observations in Australia are performed in coastal regions in the southeast and southwest, with many areas in the interior being relatively poorly covered, especially the interior arid and desert areas. Moreover, previous studies also reported the reasonable accuracy of AWRA-L with in situ measurements. Hence, these two reasons support our decision to select the AWRA-L, which integrate multiple sources i.e., in situ and remotely sensed datasets in a hydrological model framework, as the gridded reference dataset over Australia in this study.

\subsection{AMSR2 SM product}

AMSR2 on the panel of Global Change Observation Mission 1-Water is a passive microwave sensor launched by the Japan Aerospace Exploration Agency (JAXA) in 2012. AMSR2 carries the legacy of AMSR-Earth observing system with some technical improvement and performance advancements, such as an additional frequency introduced to reduce radio frequency interference (Parinussa et al., 2015; Wu et al., 2016; Cho et al., 2017). The Land Parameter Retrieval Model (LPRM) and JAXA algorithms were developed for SM retrieval from AMSR2. The LPRM algorithm was established by Vrije Universiteit Amsterdam, with assistance from the National Aeronautics Space Administration (NASA), using a simple radiative transfer model to observe the brightness temperature for estimation of SM (Mo et al., 1982). The LPRM descending SM that crosses the equator at 1:30 a.m. produces more appropriate results over Australia than the ascending SM product due to the minimum diurnal change in temperature and low vegetation (Lei et al., 2015; Cho et al., 2017). In this study, we used daily AMSR2 Level-3 descending LPRM X-band $(10.7 \mathrm{GHz})$ SM products (https:// hydro1.gesdisc.eosdis.nasa.gov) at $25 \mathrm{~km}$ spatial resolution to calculate SWDI over Australia.

\subsection{ASCAT SM product}

ASCAT is an active sensor on board Meteorological Operational Platform (MetOP) satellites. Currently, three different MetOP missions are operating: MetOP-A launched in 2006, MetOP-B launched in 2012, and MetOP-C launched in November 2018. ASCAT is in the C-band $(5.3 \mathrm{GHz})$ and provides hydrological land surface variables at a $25 \mathrm{~km}$ by $50 \mathrm{~km}$ resolution that covers approximately the entire globe in 1.5 days (Brocca et al., 2010). It measures the backscattered electromagnetic signals from Earth in the form of C-band pulses using two sets of three antennas (Wagner et al., 2013). The backscattering signals mainly depend on vegetation and surface roughness; thus, the SM product from active microwave sensors is influenced by these factors (Verhoest et al., 2008; Brocca et al., 2011). The ASCAT SM product is estimated based on the degree of saturation ranging from $0 \%$ for dry land to $100 \%$ for wet land (Su et al., 2013). The volumetric SM from ASCAT (https://eoportal.eumetsat.int) was calculated by multiplying the degree of saturation by porosity values derived from the Harmonized World Soil Database (HWSD) (Saxton et al., 1986; Kim et al., 2017).

\subsection{ERA-interim SM product}

The European Centre for Medium-Range Weather Forecasts (ECMWF) Interim Reanalysis (ERA-interim) is a global land atmospheric reanalysis product (https://apps.ecmwf.int). The Tiled ECMWF Scheme of Surface Exchanges over Land provides a land surface analysis model of ERA-interim for estimating hydrological variables (Dee et al., 2011). ERA-interim produces $S M$ for four different layers $(0-7 \mathrm{~cm}$, $7-28 \mathrm{~cm}, 28-100 \mathrm{~cm}, 100-289 \mathrm{~cm}$ ) from the surface to deep root zone (Albergel et al., 2013). In this study, we used the top layer daily ERAinterim SM products at a $0.25^{\circ}$ degree spatial resolution to calculate SWDI.

\section{Methodology}

\subsection{Rescaling soil moisture products}

SM products from various sources (satellite and land surface models) typically exhibit a wide dynamic range due to systematic biases (Koster et al., 2009; Entekhabi et al., 2010), which prevents fair comparison between SWDI values computed from individual original SM products. Rescaling techniques not only adjust the mean and standard deviation of the selected datasets to a common reference for fair comparison, but also account for both vertical and horizontal differences (Reichle and Koster, 2005; Reichle et al., 2008; Yilmaz and Crow, 2013) caused by SM obtained from different sources (satellite and models) as well as different sensors (active and passive), wavelengths (X-band and C-band), and units (volumetric SM and degree of saturation). Moreover, a rescaling technique for SWDI comparison has been used in various studies such as Albergel et al. (2008), Draper et al. (2009), and Brocca et al. (2010). In this study, a linear rescaling approach (Draper et al., 2009; Brocca et al., 2010) was used to force the AMSR2, ASCAT, and ERA-interim data to have the same mean and standard deviation as that of AWRA-L:

$S M_{R}=\left[\left(S M_{X}-\overline{S M}_{X}\right) \times \frac{\sigma_{S M_{A W R A-L}}}{\sigma_{S M_{X}}}\right]+\overline{S M}_{A W R A-L}$

Here, $S M_{\mathrm{R}}$ is the linearly rescaled $S M$ product, and $\mathrm{X}$ denotes the $\mathrm{SM}$ product of AMSR2, ASCAT, or ERA-interim. $\overline{S M}_{X}$ and $\sigma_{S M_{X}}$ are the mean and standard deviation of those three SM products, respectively. Finally, $\overline{S M}_{A W R A-L}$ and $\sigma_{S M_{A W R A-L}}$ are the mean and standard deviation of the AWRA-L SM product, respectively.

\subsection{Soil Water Deficit Index (SWDI)}

SWDI represents the drought condition by estimating the associated moisture deficit. Positive values of SWDI indicate that the SM content is greater than the field capacity (fc) and that excess water is available to plants, whereas negative values indicate a range of drought conditions. For example, the initial water stress at the start of a drought will be witnessed as the SWDI falls below zero (Mishra et al., 2017). The category of drought varies based on the magnitude of the negative values (Martínez-Fernández et al., 2015): 0 to -1 for mild drought, -2 to -5 


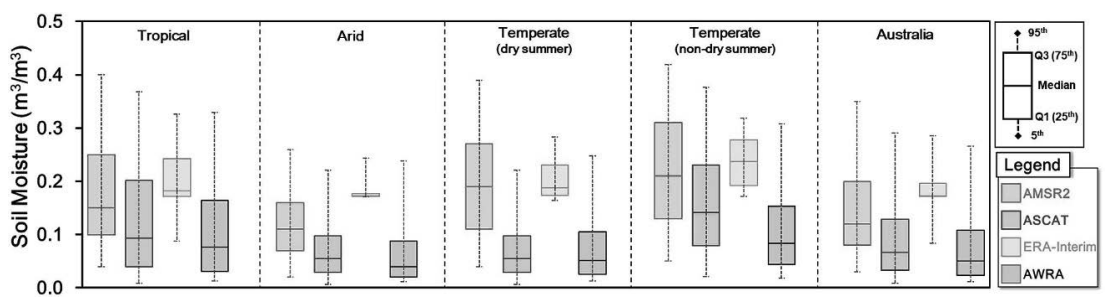

Fig. 2. Box plot of weekly mean soil moisture according to four SM products in different climate zones for the period from July 2012 to June 2017.

for moderate drought, -5 to -8 for severe drought, and -10 or below for extreme drought. To exploit its capability to represent agricultural drought, we used SWDI to translate remotely-sensed and modeled SM products into a quantified severity of agricultural drought across Australia. The water deficit is absolute (i.e., has reached the wilting point, or wp) when the SWDI is less than or equal to -10 (MartínezFernández et al., 2015; Sánchez et al., 2018). SWDI can be calculated as follows:

$S W D I=\left(\frac{\theta-\theta_{f c}}{\theta_{\mathrm{AWC}}}\right) \times 10$

$\theta_{A W C}=\theta_{f c}-\theta_{w p}$

where, $\theta$ is SM content $\left(\mathrm{m}^{3} / \mathrm{m}^{3}\right), \theta_{f c}$ is SM at $\mathrm{fc}\left(\mathrm{m}^{3} / \mathrm{m}^{3}\right), \theta_{w p}$ is SM at wp $\left(\mathrm{m}^{3} / \mathrm{m}^{3}\right)$, and $\theta_{A W C}$ is the available water content, which accounts for the distinction between $\theta_{f c}$ and $\theta_{w p} . \theta_{f c}$ and $\theta_{w p}$ are the main soil water attributes that play an important role in crop water requirements and are helpful in determining agriculture drought. These soil properties were derived from the NASA Spatial Data Access Tool at a resolution of $0.25^{\circ} \times 0.25^{\circ}$ for Australia. Satellite and model-based SM products (AMSR2, ASCAT, and ERA-interim) were processed to estimate weekly SWDI values across Australia from July 2012 to June 2017.

\subsection{Reference drought indices}

\subsubsection{Atmospheric water deficit (AWD)}

AWD is solely based on atmospheric water balance, and calculated using P and ET (Purcell et al., 2003; Torres et al., 2013). This drought index is very common and widely used because of the extensive availability of P and ET datasets. AWD is calculated as follows:

$A W D=P_{(\text {Sum_7days })}-P E T_{(\text {Sum_7days })}$

where, $\mathrm{P}_{\text {(Sum_7days) }}$ and $\mathrm{PET}_{\text {(Sum_7days) }}$ are the running sum of seven consecutive days of $\mathrm{P}$ and PET, respectively. The drought threshold for weekly AWD is $0 \mathrm{~mm}$ (Purcell et al., 2003). AWD was used to assess the SWDI from various SM products and in various climate zones for the period July 2012 to June 2017.

\subsubsection{Evaporative Stress Index (ESI) and Standardized Reconnaissance Drought Index $\left(R D I_{s t}\right)$}

ESI and $\mathrm{RDI}_{\text {st }}$ are used to evaluate the fluctuation of SWDI for agricultural drought along with the AWD. They were also calculated at weekly time scale, same as SWDI and AWD. The ESI captures the water availability and moisture stress of a surface (Choi et al., 2013, Eq. (5)). It is computed based on standardized anomalies in the ratio of actual and potential evapotranspiration $\left(f_{P E T}\right)$ (Anderson et al., 2007, 2011) and is typically used to assess hydrological and agricultural drought. ESI anomalies are expressed as pseudo z-scores normalized to a mean of 0 and a standard deviation of 1 (Eq. (6)). More detailed descriptions of the ESI are given by Anderson et al. $(2007,2011)$.

$f_{P E T}=\frac{A E T}{P E T}$

$E S I=\frac{f_{P E T}-\overline{f_{P E T}}}{\sigma\left(f_{P E T}\right)}$ where $\overline{f_{P E T}}$ and $\sigma\left(f_{P E T}\right)$ are the mean and standard deviation of $f_{P E T}$, respectively.

The RDI proposed by Tsakiris et al. (2007) is based on the ratio of $\mathrm{P}$ to PET estimation (Eq. (7)), and it is an ordinary and comprehensive index for assessment of meteorological drought (Tigkas et al., 2017). In this study, RDI has been used as a reference drought index because it requires few datasets and has high sensitivity and resilience (Thomas et al., 2016). In various recent studies (e.g. Labedzki, 2007; VicenteSerrano et al., 2012; Tigkas and Tsakiris, 2015; Chen et al., 2016), RDI was under active consideration for drought assessment in agriculture (Tigkas et al., 2017) as well as in arid and semi-arid areas (Thomas et al., 2016).

$R D I=\frac{P}{P E T}$

Assuming the value of RDI follow the normal distribution (Tsakiris and Vangelis, 2005), the standardized RDI ( $\left.\mathrm{RDI}_{\text {st }}\right)$ is calculated as;

$R D I_{s t}=\frac{R D I-\overline{R D I}}{\sigma(R D I)}$

Where, $\overline{R D I}$ is mean of RDI value, and $\sigma(R D I)$ is the standard deviation of RDI.

\subsection{Statistical analysis of soil moisture products}

SM products from AMSR2, ASCAT, and ERA-interim exhibit dissimilar characteristics over the same region and produce diverse results compared to reference datasets (Brocca et al., 2011; Kim et al., 2017). In this study, AMSR2, ASCAT, and ERA-interim SM products were assessed against the AWRA-L SM dataset at grid-scale across Australia using common statistical performance metrics, such as Bias, Root Mean Square Error (RMSE), Pearson's correlation coefficient (R), and Index of Agreement (IOA) as follows:

Bias $=\frac{1}{n} \sum_{i=i}^{n}\left(M_{i}-O_{i}\right)$

$R M S E=\sqrt{\frac{1}{n} \sum_{i=1}^{n}\left(M_{i}-O_{i}\right)^{2}}$

$R=\frac{\sum_{i=1}^{n}\left(M_{i}-\bar{M}\right)\left(O_{i}-\bar{O}\right)}{\sqrt{\sum_{i=1}^{n}\left(M_{i}-\bar{M}\right)^{2}} \sqrt{\sum_{i=1}^{n}\left(O_{i}-\bar{O}\right)^{2}}}$

$I O A=1-\frac{\sum_{i=1}^{n}\left(M_{i}-O_{i}\right)^{2}}{\sum_{i=1}^{n}\left[\left(\left|M_{i}-\bar{O}\right|\right)+\left(\left|O_{i}-\bar{O}\right|\right)\right]^{2}}$

where $M$ and $\bar{M}$ are the daily and full study period average of soil moisture, respectively, which are from AMSR2, ASCAT, and ERA-interim. $O$ and $\bar{O}$ are the daily and full study period average of reference soil moisture obtained from AWRA-L, respectively, $i$ is the number of weeks, and $n$ is total number of weeks.

AghaKouchak and Mehran (2013) demonstrated that volumetric contingency tables can detect the accuracy of $\mathrm{P}$ when the threshold value is 'greater than zero' in grids. In this study, the volumetric contingency tables were employed for assessing the drought detection capability of SWDI. 

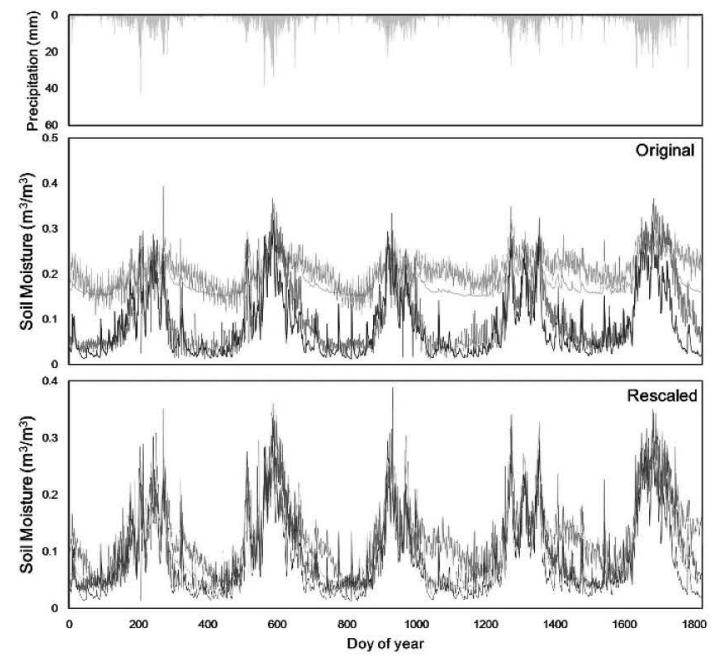

(a) Tropical zone

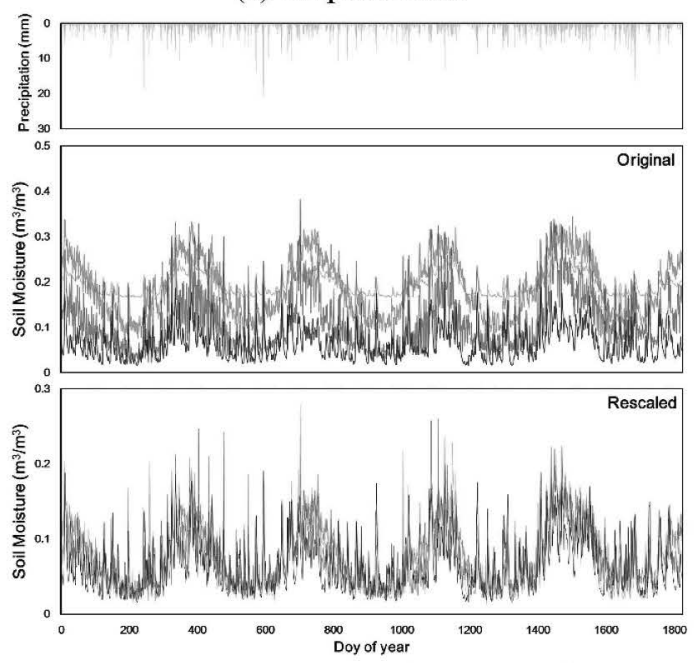

(c) Temperate zone (dry summer)
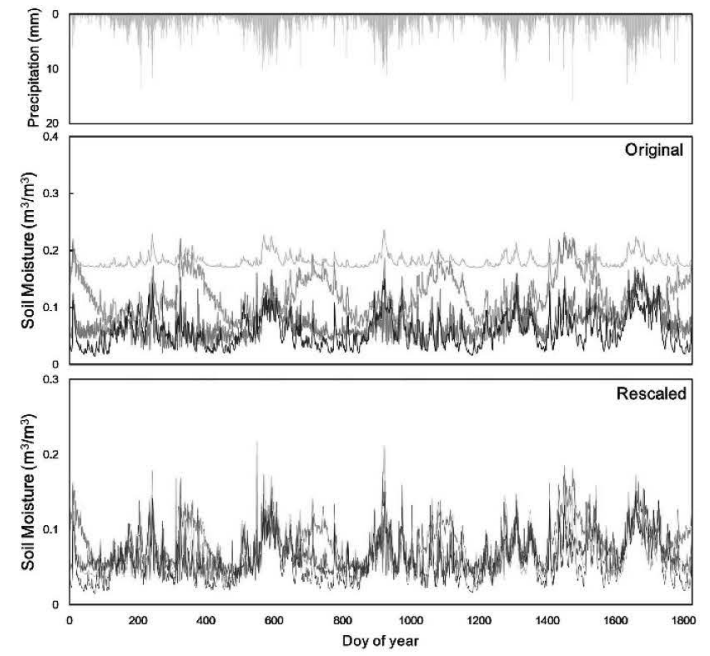

(b) Arid zone
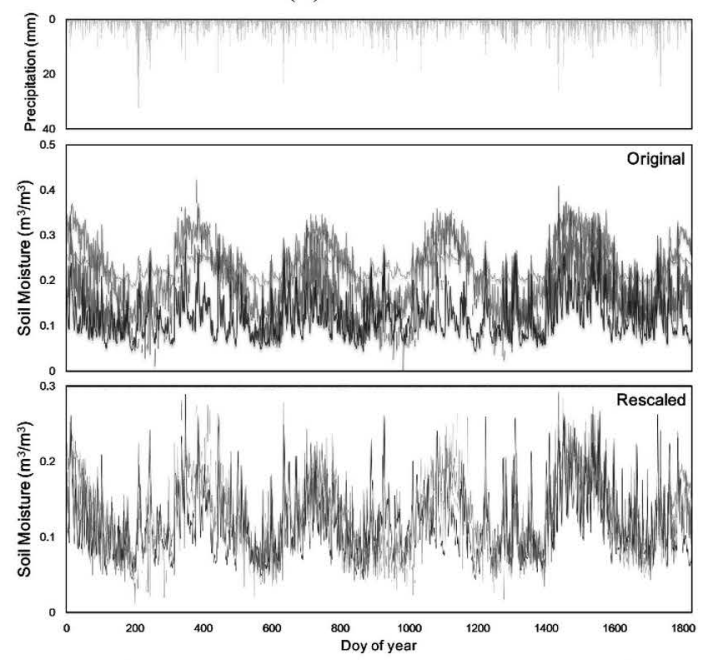

(d) Temperate zone (non-dry summer)

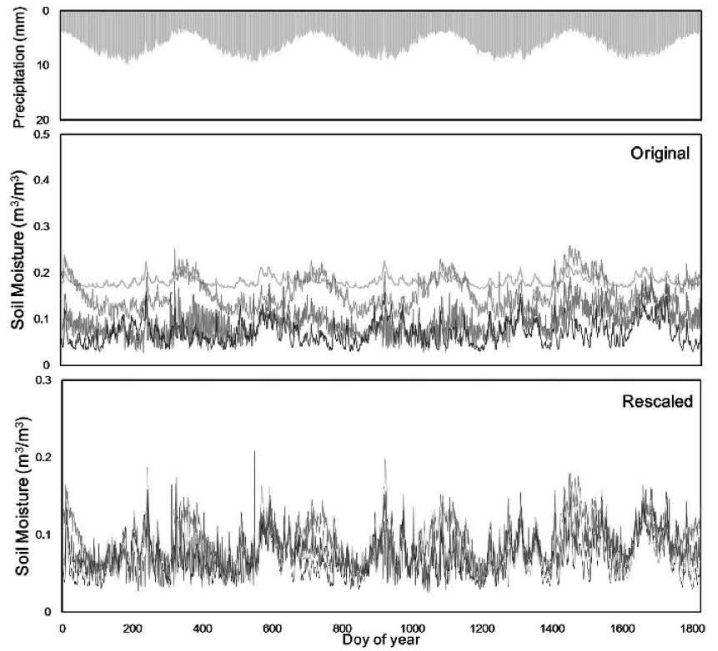

(e) Australia

- AMSR2 - ASCAT - ERA-Interim - AWRA $\square$ Precipitation

Fig. 3. Time series of daily precipitation estimated from AWRA-L (top panel of each inset) and daily SM of four SM products (middle and lower panel of each inset for original and rescaled SMs, respectively) for four climate zones (a through d) and the average across Australia (e) for the period from July 2012 to June 2017. 

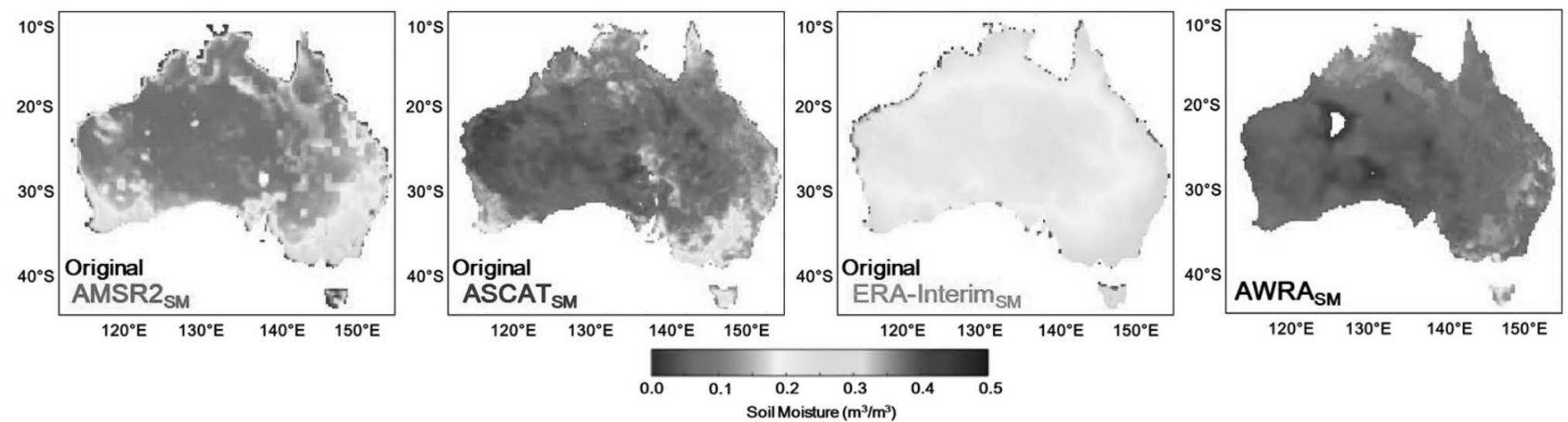

(a) SM products in original scale
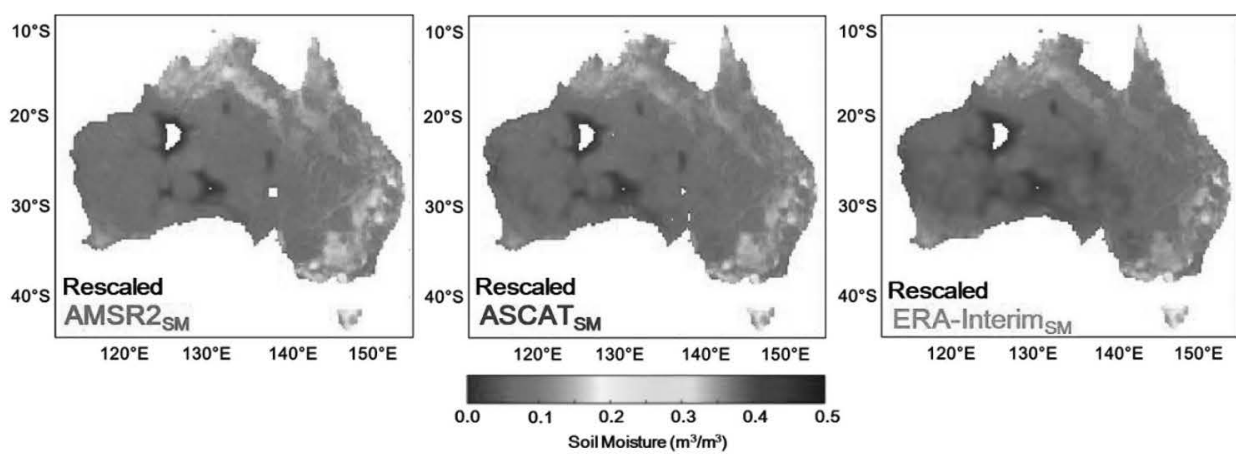

(b) Rescaled SM products

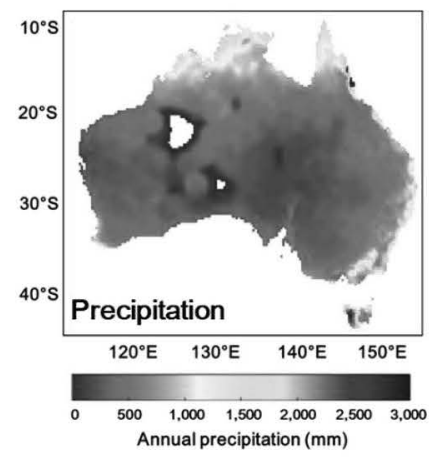

(c) Precipitation

Fig. 4. Spatial distribution of (a) mean SM from four SM products on their original scale, (b) rescaled SM to AWRA-L, and (c) annual precipitation over Australia.

The quantitative performance of these tables is based on the volume of a product on each pixel compared with the volume of the reference product on that pixel (AghaKouchak et al., 2011). Three extended volumetric contingency tables, Volumetric Hit Index (VHI), Volumetric False Alarm Ratio (VFAR), and Volumetric Miss Index (VMI), were evaluated for weekly SWDI against AWD in this study.

VHI is the volume of correctly detected SWDIs divided by the sum of the volume of correctly detected SWDIs and missed AWD (Eq. (13)). The range of VHI varies from 0 to 1 , where 1 indicates definite drought. Both products captured drought when SWDI and AWD were less than zero; this was considered a drought hit, and VHI was scored one.

$$
\begin{aligned}
\mathrm{VHI}= & \frac{\sum_{i=1}^{n}\left(\mathrm{SWDI}_{i} \mid\left(\mathrm{SWDI}_{i}<t \& \mathrm{AWD}_{i}<t\right)\right)}{\sum_{i=1}^{n}\left(\mathrm{SWDI}_{i} \mid\left(\mathrm{SWDI}_{i}<t \& \mathrm{AWD}_{i}<t\right)\right)} \\
& +\sum_{i=1}^{n}\left(\mathrm{AWD}_{i} \mid\left(\mathrm{SWDI}_{i} \geq t \& \mathrm{AWD}_{i}<t\right)\right)
\end{aligned}
$$

Here, $\mathrm{t}$ ( 0 for AWD and -10 for SWDI) is the above-mentioned threshold value in Section 3.

VFAR is the ratio of volume of false detection by SWDI to the sum of SWDIs (Eq. (14)). Here, the SWDI value was less than zero, but AWD was greater than zero. Therefore, SWDI falsely detected a drought event in reference to an AWD value.

$$
\begin{aligned}
\operatorname{VFAR}= & \frac{\sum_{i=1}^{n}\left(\operatorname{SWDI}_{i} \mid\left(\operatorname{SWDI}_{i}<t \& \mathrm{AWD}_{i} \geq t\right)\right)}{\sum_{i=1}^{n}\left(\mathrm{SWDI}_{i} \mid\left(\mathrm{SWDI}_{i}<t \& \mathrm{AWD}_{i}<t\right)\right)} \\
& +\sum_{i=1}^{n}\left(\mathrm{AWD}_{i} \mid\left(\mathrm{SWDI}_{i}<t \& \mathrm{AWD}_{i} \geq t\right)\right)
\end{aligned}
$$

VMI is the ratio of volume of missed AWD by SWDI to the sum of missed AWD and correctly detected SWDI (Eq. (15)). Here, SWDI detected a value greater than zero, indicating no drought, but AWD detected a value less than zero. Thus, SWDI missed the drought value on that pixel compared to AWD.

$$
\begin{aligned}
\mathrm{VMI}= & \frac{\sum_{i=1}^{n}\left(\mathrm{AWD}_{i} \mid\left(\mathrm{SWDI}_{i} \geq t \& \mathrm{AWD}_{i}<t\right)\right)}{\sum_{i=1}^{n}\left(\mathrm{SWDI}_{i} \mid\left(\mathrm{SWDI}_{i}<t \& \mathrm{AWD}_{i}<t\right)\right)} \\
& +\sum_{i=1}^{n}\left(\mathrm{AWD}_{i} \mid\left(\mathrm{SWDI}_{i} \geq t \& \mathrm{AWD}_{i}<t\right)\right)
\end{aligned}
$$

The VFAR and VMI values ranged from 0 to 1 , with 0 representing a perfect score.

\section{Results and discussion}

4.1. Inter-comparison of SM products across Australia for various climate zones

Fig. 2 shows the box plots of all four original SM products as a visual interpretation of median and range of SM values in Australia and its different climate zones. ERA-interim showed higher SM content in all climate zones but exhibited a particularly low dynamic range. Both ASCAT and AWRA-L showed low median values in all climate zones. All SM products had a substantial dynamic range in tropical and temperate NDS zones that might be explained by the high seasonal variation of precipitation associated with an intensified hydrological cycle (Held and Soden, 2006; Zohaib et al., 2017). This result is in consistent with Rowell et al. (1995) for tropical regions, which showed high variability of SM in tropical climate zones of Northern Africa. The low SM variability in the arid zone was captured by all products, with median values of $0.11 \mathrm{~m}^{3} / \mathrm{m}^{3}, 0.06 \mathrm{~m}^{3} / \mathrm{m}^{3}, 0.18 \mathrm{~m}^{3} / \mathrm{m}^{3}$, and $0.05 \mathrm{~m}^{3} / \mathrm{m}^{3}$ for AMSR2, ASCAT, ERA-interim, and AWRA-L, respectively. In the temperate DS zone, SM contents were relatively higher than those in the arid zone despite similar P patterns; this phenomenon might be attributed to soil texture and temperature differences between these two zones (Ulaby et al., 1978; Entekhabi et al., 1994).

As shown in Fig. 2, the wide range of median values of individual SM products in their original scale will lead to erroneous detection and biased comparisons of droughts when using multiple SM products. 

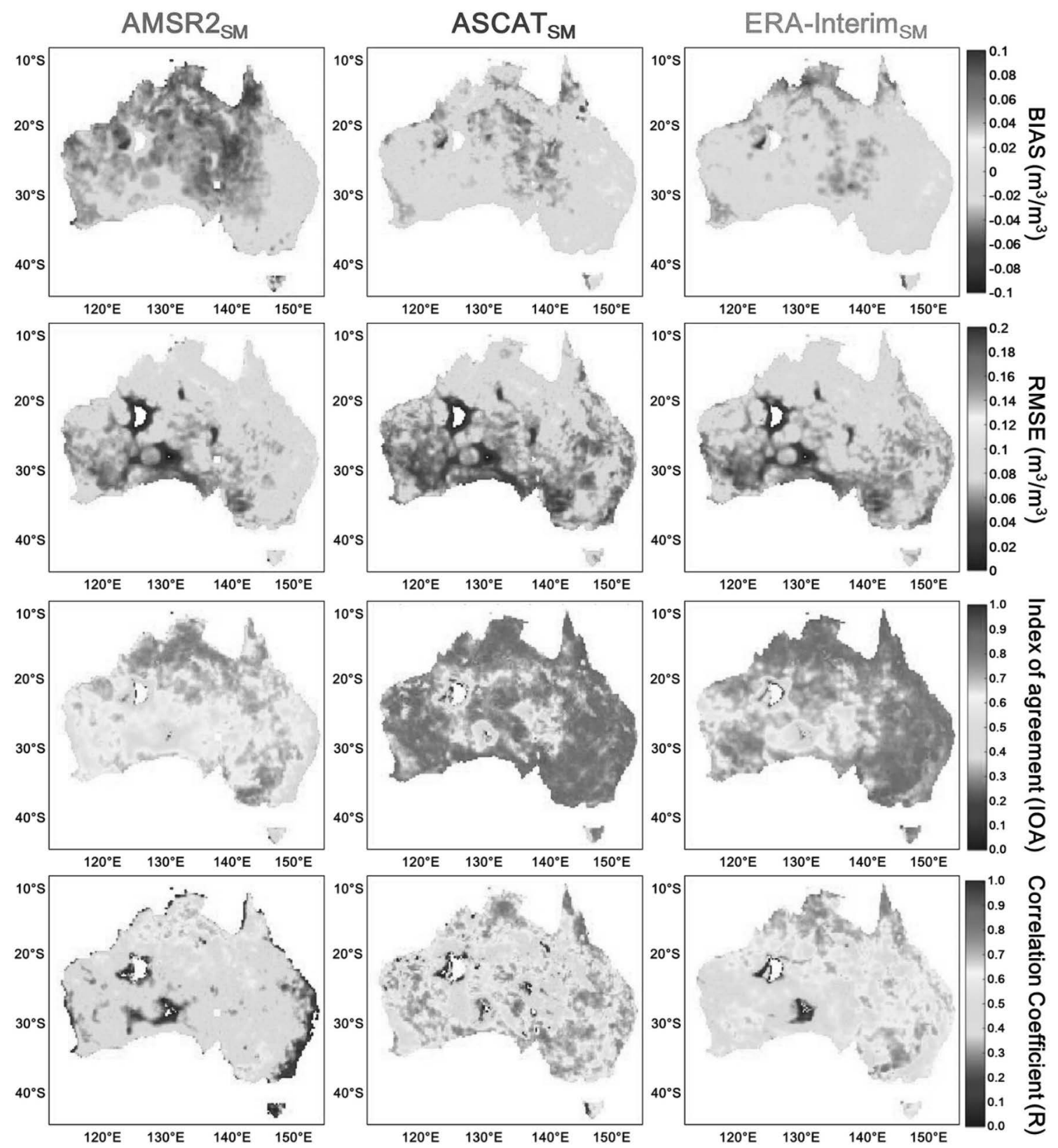

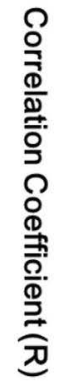

Fig. 5. Spatial distribution of performance statistics for rescaled SM products.

Therefore, AMSR2, ASCAT, and ERA-interim SM need to be rescaled against a reference SM product (i.e., AWRA-L) to present an unbiased comparison while maintaining the relative magnitudes of mean and standard deviation of each product (Draper et al., 2009; Brocca et al., 2010, 2011).

The spatially-averaged time-series of daily $\mathrm{P}$ and daily SM products (AMSR2, ASCAT, and ERA-interim) were compared against AWRA-L SM in four climate zones (tropical, arid, temperate DS, and temperate NDS) and entire Australia in Fig. 3. Generally, all SM products follow the P events closely in Australia and its climate zones (except in the arid climate zone) and show inconsistent temporal patterns. However, the dynamic ranges of the AMSR2 and ERA-interim showed substantial positive biased compared to the AWRA-L SM. The original AMSR2 SM product overestimated values relative to the AWRA-L SM in all climate zones. However, the amplitude and variations of rescaled AMSR2 SM products matched well with the AWRA-L SM. Moreover, both original and rescaled AMSR2 SM showed prompt reactions to $\mathrm{P}$ events in all climate zones. This pattern was similar to the swift reaction of AMSR2
SM from the LPRM algorithm, which overestimated the JAXA soil moisture for low P events (Kim et al., 2015).

The original ERA-interim SM also overestimated the results relative to the AWRA-L SM and exhibited a narrow range over Australia and its climate zones (Figs. 2 and 3). This is caused by the omission in the ERAinterim assimilation system to account for ground-based P. Rather, in situ measurements of $\mathrm{T}$ and humidity were used to account for rain events (Albergel et al., 2012). However, the mean and amplitude of variations matched well with the AWRA-L SM after linear rescaling. As expected, both original and rescaled ASCAT SM products matched well with the AWRA-L SM product in Australia. This is because ASCAT SM was assimilated into the AWRA-L model to generate daily top-layer and shallow root-zone SM estimates (Renzullo et al., 2014). Moreover, Holgate et al. (2016) showed that the ASCAT SM corresponded well with the in situ sites spread across all of Australia but was worse in the arid climate zone. Furthermore, the arid climate zone typically exhibits low SM values for all products compared to other climate zones due to the low $\mathrm{P}$ and underlying surface conditions along with high 


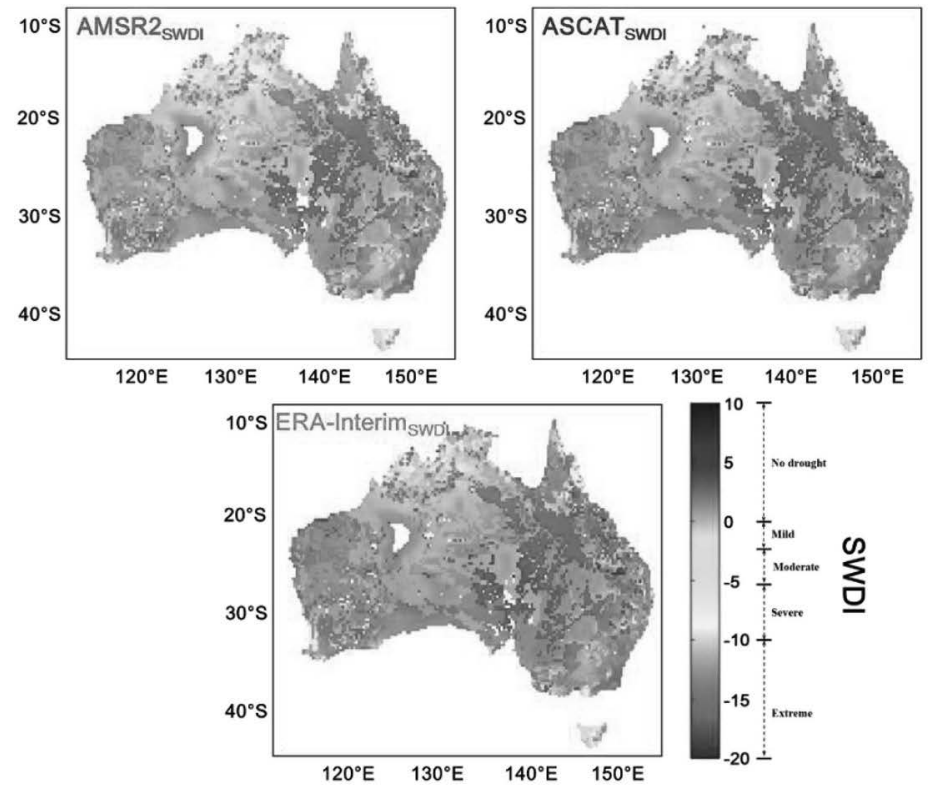

(a) SWDI

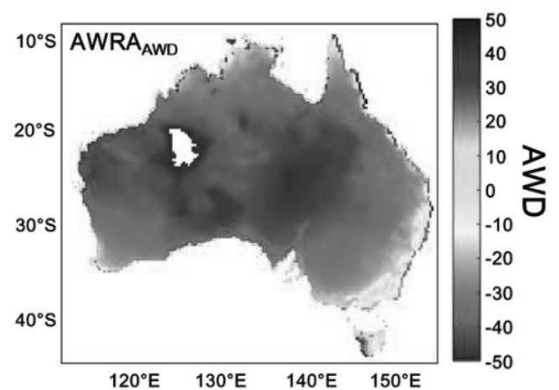

(b) AWD

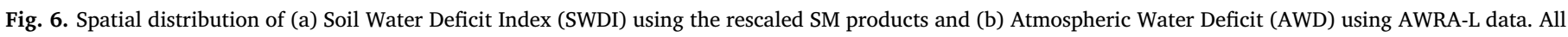
values were averaged for the period from July 2012 to June 2017.

temperature. As most of Australia is covered by arid zones, i.e., $70 \%$ (Fig. 1), spatially-averaged daily SM over Australia remained low, and fewer SM fluctuations were observed.

Fig. 4 presents the spatial distributions of the mean from various SM products during the study period. The mean distribution of the AWRA-L SM showed lower variability of SM over the entire Australia in comparison with those of other SM products (Fig. 4a). In particular, the AWRA-L SM was missing values for the northwestern part of Australia. This may be because most of the precipitation network was located in coastal regions as well as the southeast and southwest parts of the country, and was lacking in the interior arid and desert areas (Tregoning et al., 2012). Therefore, the northwest (i.e., the interior arid and desert areas) of Australia led to errors in hydrological responses in the AWRA-L model due to the absence of precipitation datasets (Fig. 4c). Overall, we observed that the central part of Australia has low SM contents (arid regions), while the northern (tropical) and southeastern parts of Australia (temperate NDS) had higher contents for all three SM products during the study period. The range of SM values for original SM products (i.e., AMSR2, ASCAT, and ERA-Interim) differed considerably from that of the AWRA-L (Fig. 4a), whereas those of rescaled SM products (Fig. 4b) exhibited a similar tendency to that of the AWRA-L and also followed the pattern of P (Fig. 4c). Further analysis will be performed with the rescaled SM products to produce an unbiased comparison of agricultural drought indices based on various SM products.

Fig. 5 shows the spatial maps of statistical comparisons (Bias, RMSE, IOA, and R) between rescaled SM products (i.e., AMSR2, ASCAT, and ERA-interim) and AWRA-L SM over Australia. As shown in Fig. 5, the ASCAT and ERA-interim exhibited reasonable performance (lower bias and RMSE and higher IOA and R), whereas, the AMSR2 showed poor performance in Australia compared to the two other SM products (ASCAT and ERA-interim). This is likely explained by the low surface temperature susceptibility of the active sensor, as addressed by Kim et al. (2018). In the tropical regions of Australia, ASCAT had reasonable performance than the AMSR2. The reason for the disparity of AMSR2 in the tropical zone may be because the SM estimated from the passive microwave sensor may produce uncertainties in densely vegetated areas because of the effect of higher vegetation water content (Scipal et al., 2008; Dorigo et al., 2010; Al-Yaari et al., 2014; Kim et al., 2018).
Moreover, the swift reaction of AMSR2 SM to low $\mathrm{P}$ events also causes temporal inconsistencies with AWRA-L SM (Fig. 3). The temporal pattern of AMSR2 in the temperate DS and NDS zones showed higher bias and RMSE than other climate zones. These regions of the study area are densely populated and have urban infrastructure that hinders SM estimation, resulting in higher bias and RMSE (Holgate et al., 2016). The spatial distribution of R and IOA indicated that ASCAT SM products had poor performance in arid regions and good performance in tropical regions (Fig. 5). These results are similar to previous studies of Kim et al. (2018) and Wagner et al. (2013), who reported that surface roughness and subsurface heterogeneity highly influenced ASCAT SM estimation.

\subsection{Agricultural drought analysis over Australia}

The weekly SWDI time-series is derived based on three rescaled SM products (i.e., AMSR2, ASCAT, and ERA-interim). First, the SWDI was calculated at a daily time step and then was aggregated into a weekly temporal scale (Fernendez et al., 2016; Mishra et al., 2017). The weekly SWDI obtained from the rescaled SM products was compared with the weekly AWD over Australia and its four climate zones to evaluate the spatial severity pattern of the agricultural drought (Fig. 6). The overall SWDI distribution for three rescaled SM products during the study period suggested that the arid zone was largely affected by agricultural drought, indicating severe to extreme agricultural drought based on the classification of SWDI values for drought categories (Martínez-Fernánde et al., 2015). Generally, the temperate DS, temperate NDS, and tropical zones were under severe drought from 2012 to 2017.

Fig. 7 shows a temporal comparison of SWDI with AWD, ESI, and $\mathrm{RDI}_{\mathrm{st}}$ in different climate zones of Australia. Despite the different drought index values, their temporal patterns match well across all climate zones (Fig. 7a-d). In general, the SWDIs estimated from three rescaled SM products considerably followed the drought cycles of AWD and ESI. However, the AMSR2-SWDI indicated abrupt variability in the winter season compared to other SWDI values in all climate zones (Fig. 7a-d). This can be explained by the high sensitivity of AMSR2 SM to small variations in precipitation (Su et al., 2013; Cho et al., 2017). Overall, the temporal patterns of all drought indices (either meteorological or agricultural) followed the temporal pattern of precipitation 


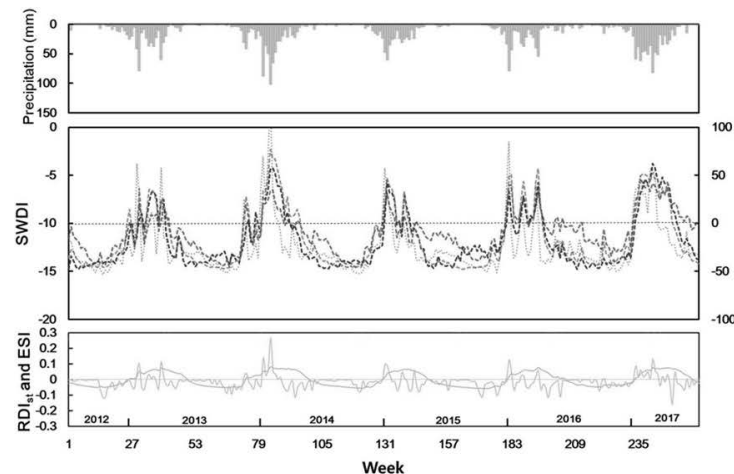

(a) Tropical Zone

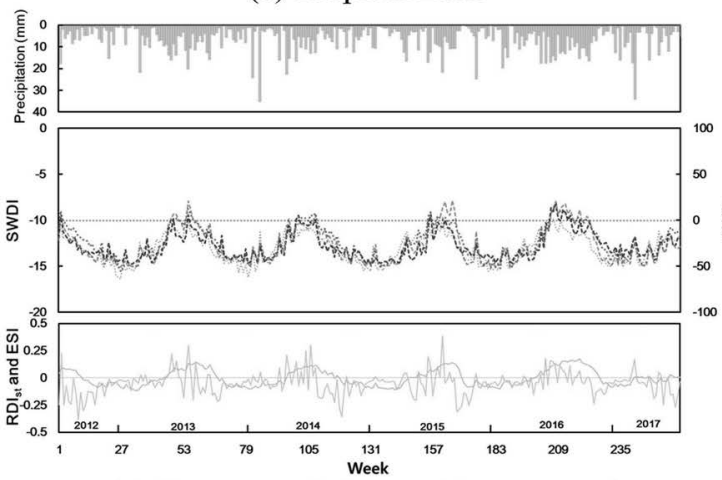

(c) Temperate DS zone (dry summer)

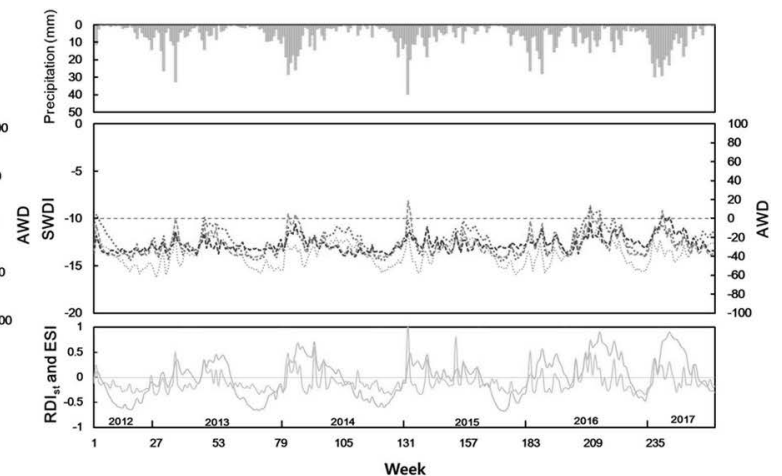

(b) Arid Zone

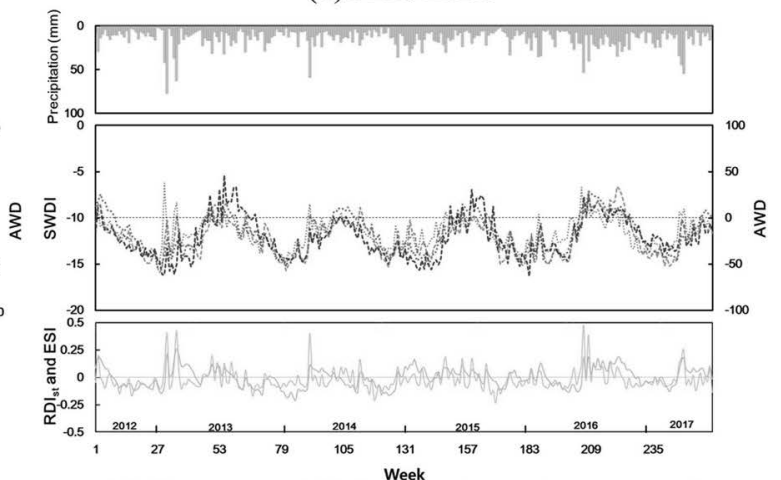

(d) Temperate NDS zone (non-dry summer)
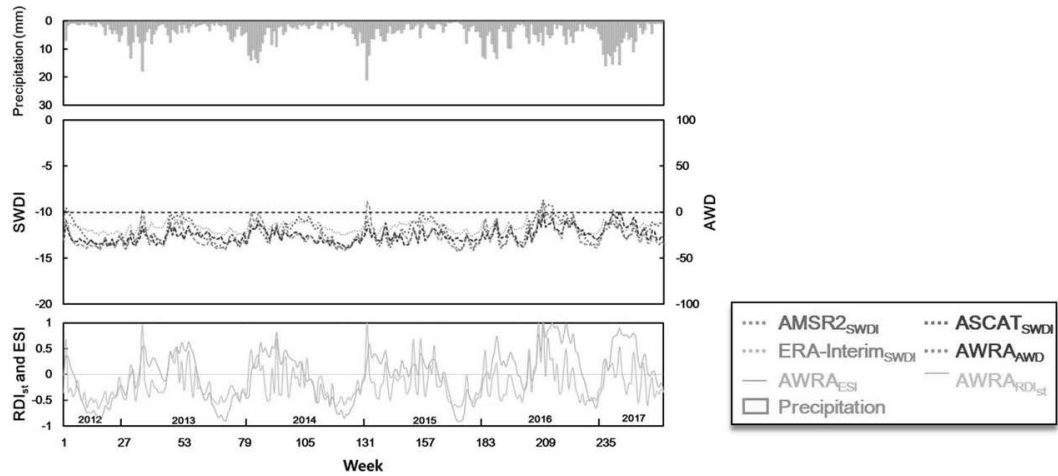

(e) Australia

Fig. 7. Time series of weekly precipitation from AWRA-L (upper), the weekly Soil Water Deficit Index (SWDI) from three rescaled and AWRA-L SM products (middle),

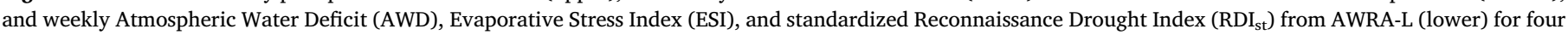
different climate zones (from a to d) and the average across Australia (e).

found in Mohammed and Scholz (2017). For the tropical zone (Fig. 7a), all drought indices captured an increasing trend (extreme to nondrought condition) in the rainy season and a decreasing trend (non- and extreme-drought condition) in the non-rainy season over the study period. This phenomenon demonstrated that the fluctuation in drought conditions depends on the amount of heavy precipitation (Kim et al., 2015).

The SWDI is all climate zones of Australia (Fig. 7a-d) ranged from approximately -15 to -3 and was rarely surpassed. Fig. 7e shows that the mean SWDI for all climate zones in Australia was below - 10 (severe to extreme drought conditions). Both SWDI and AWD are below the threshold line of severe drought (SWDI $<-10$ and AWD $<0$ ), which indicate that Australia is suffering from a continuous drought condition during the study period.

Specifically, for the tropical and temperate NDS zones (Fig. 7a and d), SWDI and AWD showed similar drought patterns (moderate to severe drought conditions) for most of the study period. Moreover, $\mathrm{RDI}_{\mathrm{st}}$ and ESI showed a duration cycle of weak drought compared with arid and temperate DS zones. For the arid and temperate DS zones, drought conditions appeared as consecutive patterns (SWDI $\leq-10$, AWD $<0$, and negative $\mathrm{RDI}_{\mathrm{st}}$ and ESI) and intermittent patterns (short periods of severe drought and long periods of extreme drought), respectively. This might be explained by the small amount of precipitation and high temperature, which led to more extreme drought conditions in arid and temperate DS zones than other zones (Mohammed and Scholz, 2017). This tendency could therefore be referred to as "water limited" compared to tropical and temperature NDS zones. Moreover, the difference between AET and PET is relatively large over the arid zone, and actual evapotranspiration is approximately $10 \%$ of the potential evapotranspiration (Nagler et al., 2007) except for the few days after ample precipitation. Thus, the variation of the ESI in arid and temperature NDS zones was lower than in other zones.

\subsection{Assessment of drought detection}

Fig. 8 shows the spatial distribution of extended volumetric contingency tables to assess the drought detection capability of SWDIs calculated from three rescaled SM products against AWD at a weekly 

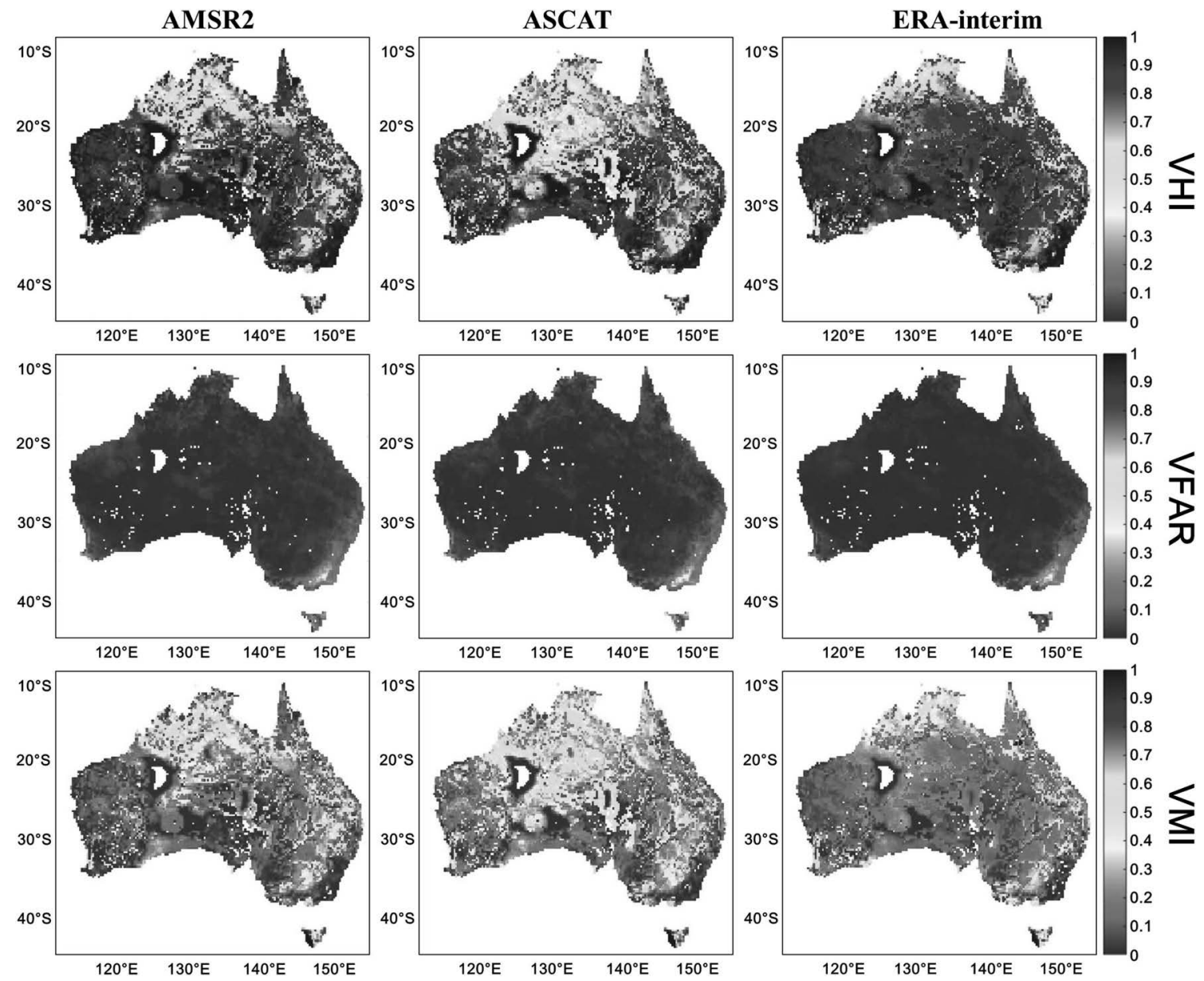

Fig. 8. Spatial distribution of extended volumetric contingency tables (volumetric hit index (VHI), volumetric false alarm ratio (VFAR), and volumetric miss index (VMI)) for Soil Water Deficit Index (SWDI) using three rescaled SM products against Atmospheric Water Deficit (AWD) using AWRA-L.

Table 1

Average values of various extended volumetric contingency tables over Australia and its four climate zones for the period from July 2012 to June 2017.

\begin{tabular}{lllll}
\hline Climate zone & Product & VHI & VFAR & VMI \\
\hline \multirow{2}{*}{ Australia } & & & & \\
& AMSR2 & 0.700 & 0.035 & 0.300 \\
& ASCAT & 0.728 & 0.040 & 0.272 \\
ERA-Interim & 0.787 & 0.029 & 0.213 \\
Tropical & & & \\
& AMSR2 & 0.437 & 0.067 & 0.563 \\
ASCAT & 0.571 & 0.070 & 0.429 \\
ERA-Interim & 0.576 & 0.045 & 0.426 \\
Arid & AMSR2 & 0.690 & 0.021 & 0.333 \\
& ASCAT & 0.707 & 0.030 & 0.304 \\
ERA-Interim & 0.796 & 0.020 & 0.210 \\
Temperature (dry summer) & & & \\
& AMSR2 & 0.780 & 0.036 & 0.239 \\
ASCAT & 0.820 & 0.040 & 0.185 \\
ERA-Interim & 0.819 & 0.031 & 0.186 \\
Temperature (non-dry & summer) & & & \\
AMSR2 & 0.730 & 0.114 & 0.289 \\
ASCAT & 0.801 & 0.102 & 0.216 \\
& ERA-Interim & 0.781 & 0.084 & 0.233 \\
\hline
\end{tabular}

*VHI: Volumetric Hit Index, VFAR: Volumetric False Alarm Ratio, VMI: Volumetric Miss Index. time scale. In addition, the mean values of those extended volumetric contingency tables summarized for each climate zone and entire Australia are provided in Table 1 . VHI shows that the SWDIs of all three SM products have acceptable drought detection capability over Australia (0.700-0.787, with an average of 0.738, Fig. 8 and Table 1). In addition, the average VHI for arid and temperate zones showed reasonable values (0.690-0.820), whereas the average VHI for the tropical zone shows 0.437 for the AMSR2, 0.571 for the ASCAT, and 0.576 for the ERA-interim (Table 1). VFAR specifies the volume of drought detected falsely when SWDI identifies drought, while AWD does not signify drought. The spatial distribution of VFAR showed that the values close to zero specifying drought were not detected falsely by SWDI except in the southwest, i.e., in the temperate NDS zone. The VFAR values for all three products range from 0.020 to 0.114 over four climate zones with a mean of 0.035, 0.040, and 0.029 for AMSR2, ASCAT, and ERA-interim, respectively. VMI identifies the number of drought events missed volumetrically by SWDI compared to AWD. The spatial patterns of VMI for all products resembled the inverse of VHI, i.e., high misses in tropical zones. In the tropical zone, the average VMI values for AMSR2, ASCAT, and ERA-interim were $0.563,0.429$, and 0.426 , respectively. Similarly, other climate zones also had low mean VMI values ranging from 0.210 to 0.333 (Table 1). Generally, all products showed a moderate VHI, low VFAR, and moderate VMI in the tropical zone, indicating a high number of misses in this climate zone. This can be explained by the SM-P-ET 
feedback in this hot and humid region, which is characterized by low SM memory (Seneviratne et al., 2006) and intensified hydrological cycle (Zohaib et al., 2017), causing high ET. In other climate zones, the comparable range of contingency table matrices was observed and characterized by higher drought detection capability by SWDI over Australia after removing systematic errors from SM products.

\section{Summary and conclusion}

This study was carried out to evaluate the variation and distribution of agricultural drought from various SM products across Australia and its four climate zones (i.e., tropical, arid, temperate DS, and temperate NDS) from July 2012 to June 2017. We estimated SWDI as an agricultural drought index from two satellite remote sensing SM products (AMSR2 and ASCAT) and one model SM products (ERA-interim). First, the SM products were compared on a grid scale against the AWRA-L as a reference SM product. Second, the SWDIs calculated based on all SM products and soil characteristics (i.e., fc and $\mathrm{wp}$ ) were compared with the AWD index derived from P and PET of AWRA-L. The three SM products (AMSR2, ASCAT, and ERA-interim) captured the temporal pattern of AWRA-L satisfactorily in Australia. However, AMSR2 and ERA-interim showed high positive bias. The systematic bias was removed by linearly rescaling three SM products against AWRA-L to enable fair comparison of agricultural drought using various SM products. The trends in rescaled SM products from AMSR2, ASCAT, and ERAInterim agreed with the AWRA-L, although the AMSR2 SM indicated slight variation by showing prompt reactions to low precipitation events. In addition, the difference between ASCAT SM and AWRA-L for arid regions could be caused by the limitation of active microwave sensors in estimating SM due to surface roughness, subsurface heterogeneity, and inherent errors in the retrieval algorithm.

The results of SWDIs from three SM products were compared with the AWD, ESI, and $\mathrm{RDI}_{\text {st }}$ drought indexes, estimated from the AWRA-L for entire Australia and its climate zones. The SWDI tended to reflect the AWD, ESI, and RDI $\mathrm{st}_{\mathrm{st}}$. Based on a comparison of all regions of Australia, the SWDI average was below -10 . This result indicates that most regions in Australia have suffered from extreme drought conditions.

The performance of each SWDI was examined against AWD using extended volumetric contingency tables was examined for Australia and its four climate zones. All SM products showed acceptable drought detection skills at about $70 \%$ on average. The results of extended volumetric contingency tables presented performance in order from best to worst as ASCAT, ERA-interim, and AMSR2 in the three climate zones other than the arid zone, which followed the best-worst order of ERAinterim, ASCAT, and AMSR2. Overall, the ranking of these three datasets indicates their tendency to produce better SM products and SWDIs for Australia (ASCAT > ERA-interim > AMSR2).

\section{Acknowledgements}

This research was supported by Basic Science Research Program through the National Research Foundation of Korea (NRF) funded by the Ministry of Education (NRF-2018R1D1A1B07049029). This research was supported by Space Core Technology Development Program through the NRF funded by the Ministry of Science and ICT (NRF2014M1A3A3A02034789). This research was also supported by the National Research Foundation of Korea (NRF) grant funded by the Korea government (MSIT) (NRF-2016R1A2B4008312).

\section{Appendix A. Supplementary data}

Supplementary data to this article can be found online at https:// doi.org/10.1016/j.jaridenv.2019.04.007.

\section{References}

AghaKouchak, A., Mehran, A., 2013. Extended contingency table: performance metrics for satellite observations and climate model simulations. Water Resour. Res. 49 (10), 7144-7149.

AghaKouchak, A., Behrangi, A., Sorooshian, S., Hsu, K., Amitai, E., 2011. Evaluation of satellite-retrieved extreme precipitation rates across the central United States. J. Geophys. Res.: Atmosphere 116 (D2). https://doi.org/10.1029/2010JD014741.

AghaKouchak, A., Cheng, L., Mazdiyasni, O., Farahmand, A., 2014. Global warming and changes in risk of concurrent climate extremes: insights from the 2014 California drought. Geophys. Res. Lett. 41 (24), 8847-8852. https://doi.org/10.1002/ 2014GL062308.

AghaKouchak, A., Farahmand, A., Melton, F.S., Teixeira, J., Anderson, M.C., Wardlow, B.D., Hain, C.R., 2015a. Remote sensing of drought: progress, challenges and opportunities. Rev. Geophys. 53 (2), 452-480. https://doi.org/10.1002/ 2014 RG000456.

AghaKouchak, A., Farahmand, A., Melton, F.S., Teixeira, J., Anderson, M.C., Wardlow, B.D., Hain, C.R., 2015b. Remote sensing of drought: progress, challenges and opportunities. Rev. Geophys. 53 (2), 452-480.

Al-Yaari, A., Wigneron, J.P., Ducharne, A., Kerr, Y.H., Wagner, W., De Lannoy, G., Reichle, R., Al Bitar, A., Dorigo, W., Richaume, P., Mialon, A., 2014. Global-scale comparison of passive (SMOS) and active (ASCAT) satellite based microwave soil moisture retrievals with soil moisture simulations (MERRA-Land). Remote Sens. Environ. 152, 614-626. https://doi.org/10.1016/j.rse.2014.07.013.

Albergel, C., Rüdiger, C., Pellarin, T., Calvet, J.-C., Fritz, N., Froissard, F., Suquia, D., Petitpa, A., Piguet, B., Martin, E., 2008. From near-surface to root-zone soil moisture using an exponential filter: an assessment of the method based on in-situ observations and model simulations. Hydrol. Earth Syst. Sci. 12, 1323-1337. https://doi.org/10. 5194/hess-12-1323-2008.

Albergel, C., Dorigo, W., Reichle, R.H., Balsamo, G., De Rosnay, P., Muñoz-Sabater, J., Isaksen, L., De Jeu, R., Wagner, W., 2013. Skill and global trend analysis of soil moisture from reanalyses and microwave remote sensing. J. Hydrometeorol. 14 (4), 1259-1277.

Albergel, C., de Rosnay, P., Gruhier, C., Muñoz-Sabater, J., Hasenauer, S., Isaksen, L., Kerr, Y., Wagner, W., 2012. Evaluation of remotely sensed and modelled soil moisture products using global ground-based in situ observations. Remote Sens. Environ. 118, 215-226. https://doi.org/10.1016/j.rse.2011.11.017.

Ambaw, G.M., 2013. Satellite Based Remote Sensing of Soil Moisture for Drought Detection and Monitoring in the Horn of Africa. PhD thesis. Politecnico di Torino, Turin.

Anderson, M.C., Norman, J.M., Mecikalski, J.R., Otkin, J.A., Kustas, W.P., 2007. A climatological study of evapotranspiration and moisture stress across the continental United States based on thermal remote sensing: 1. Model formulation. J. Geophys. Res.: Atmos. 112 (D10), D10117. https://doi.org/10.1029/2006JD007506.

Anderson, M.C., Hain, C., Wardlow, B., Pimstein, A., Mecikalski, J.R., Kustas, W.P., 2011 Evaluation of drought indices based on thermal remote sensing of evapotranspiration over the continental United States. J. Clim. 24 (8), 2025-2044. https://doi.org/10. $1175 / 2010$ JCLI3812.1.

Balsamo, G., Albergel, C., Beljaars, A., Boussetta, S., Brun, E., Cloke, H., Dee, D., Dutra, E., Muñoz-Sabater, J., Pappenberger, F., de Rosnay, P., Stockdale, T., Vitart, F., 2015. ERA-Interim/Land: a global land surface reanalysis data set. Hydrol. Earth Syst. Sci. 19 (1), 389-407. https://doi.org/10.5194/hess-19-389-2015.

Bateni, S.M., Entekhabi, D., 2012. Relative efficiency of land surface energy balance components. Water Resour. Res. 48 (4). https://doi.org/10.1029/2011WR011357.

Brocca, L., Melone, F., Moramarco, T., Wagner, W., Hasenauer, S., 2010. ASCAT soil wetness index validation through in situ and modeled soil moisture data in central Italy. Remote Sens. Environ. 114 (11), 2745-2755. https://doi.org/10.1016/j.rse. 2010.06.009 Bureau of Meteorology, Australia http://www.bom.gov.au/climate/ drought/.

Brocca, L., Hasenauer, S., Lacava, T., Melone, F., Moramarco, T., Wagner, W., Dorigo, W., Matgen, P., Martínez-Fernández, J., Llorens, P., Latron, J., Marting, C., Bittellih, M., 2011. Soil moisture estimation through ASCAT and AMSR-E sensors: an intercomparison and validation study across Europe. Remote Sens. Environ. 115 (12), 3390-3408. https://doi.org/10.1016/j.rse.2011.08.003.

Brocca, L., Ponziani, F., Moramarco, T., Melone, F., Berni, N., Wagner, W., 2012. Improving landslide forecasting using ASCAT-derived soil moisture data: a case study of the Torgiovannetto landslide in central Italy. Remote Sens. 4 (5), 1232-1244.

Chen, T., Xia, G., Liu, T., Chen, W., Chi, D., 2016. Assessment of drought impact on main cereal crops using a standardized precipitation evapotranspiration index in Liaoning Province, China. Sustainability 8 (10), 1069.

Chiew, F.H.S., Potter, N.J., Vaze, J., Petheram, C., Zhang, L., Teng, J., Post, D.A., 2014. Observed hydrologic non-stationarity in far south-eastern Australia: implications for modelling and prediction. Stoch. Environ. Res. Risk Assess. 28 (1), 3-15.

Cho, E., Su, C.H., Ryu, D., Kim, H., Choi, M., 2017. Does AMSR2 produce better soil moisture retrievals than AMSR-E over Australia? Remote Sens. Environ. 188, 95-105. https://doi.org/10.1016/j.rse.2016.10.050.

Choi, M., Jacobs, J.M., Anderson, M.C., Bosch, D.D., 2013. Evaluation of drought indices via remotely sensed data with hydrological variables. J. Hydrol. 476, 265-273. https://doi.org/10.1016/j.jhydrol.2012.10.042.

Dai, A., 2013. Increasing drought under global warming in observations and models. Nat. Clim. Change 3 (1), 52-58. https://doi.org/10.1038/nclimate1633.

Dee, D.P., Uppala, S.M., Simmons, A.J., Berrisford, P., Poli, P., Kobayashi, S., Andrae, U., Balmaseda, M.A., Balsamo, G., Bauer, P., Bechtold, P., Beljaars, A.C.M., van de Berg, L., Bidlot, J., Bormann, N., Delsol, C., Dragani, R., Fuentes, M., Geer, A.J., Haimberger, L., Healy, S.B., Hersbach, H., Hólm, E.V., Isaksen, L., Kållberg, P., 
Köhler, M., Matricardi, M., McNally, A.P., Monge-Sanz, B.M., Morcrette, J.-J., Park, B.-K., Peubey, C., de Rosnay, P., Tavolato, C., Thépaut, J.-N., Vitart, F., 2011. The ERA-Interim reanalysis: configuration and performance of the data assimilation system. Q. J. R. Meteorol. Soc. 137 (656), 553-597. https://doi.org/10.1002/qj.828.

Dorigo, W.A., Gruber, A., De Jeu, R.A.M., Wagner, W., Stacke, T., Loew, A., Albergel, C., Brocca, L., Chung, D., Parinussa, R.M., Kidd, R., 2015. Evaluation of the ESA CCI soil moisture product using ground-based observations. Remote Sens. Environ. 162, 380-395. https://doi.org/10.1016/j.rse.2014.07.023.

Dorigo, W., Scipal, K., Parinussa, R.M., Liu, Y.Y., Wagner, W., De Jeu, R.A., Naeimi, V., 2010. Error characterisation of global active and passive microwave soil moisture datasets. Hydrol. Earth Syst. Sci. 14, 2605-2616.

Draper, C.S., Walker, J.P., Steinle, P.J., de Jeu, R.A., Holmes, T.R., 2009. An evaluation of AMSR-E derived soil moisture over Australia. Remote Sens. Environ. 113, 703-710. https://doi:10.1016/j.rse.2008.11.011.

Entekhabi, D., Nakamura, H., Njoku, E.G., 1994. Solving the inverse problem for soil moisture and temperature profiles by sequential assimilation of multifrequency remotely sensed observations. IEEE Trans. Geosci. Remote Sens. 32 (2), 438-448. https://doi.org/10.1109/36.295058.

Entekhabi, D., Njoku, E.G., O'Neill, P.E., Kellogg, K.H., Crow, W.T., Edelstein, W.N., Entin, J.K., Goodman, S.D., Jackson, T.J., Johnson, J., Kimball, J., Piepmeier, J.R., Koster, R.D., Martin, N., McDonald, K.C., Moghaddam, M., Moran, S., Reichle, R., Shi, J.C., Spencer, M.W., Thurman, S.W., Tsang, L., Zyl, J.V., 2010. The soil moisture active passive (SMAP) mission. Proc. IEEE 98 (5), 704-716. https://doi.org/10.1109/ JPROC.2010.2043918.

Hao, Z., AghaKouchak, A., 2013. Multivariate standardized drought index: a parametric multi-index model. Adv. Water Resour. 57, 12-18. https://doi.org/10.1016/j. advwatres.2013.03.009.

Held, I.M., Soden, B.J., 2006. Robust responses of the hydrological cycle to global warming. J. Clim. 19 (21), 5686-5699. https://doi.org/10.1175/JCLI3990.1.

Holgate, C.M., De Jeu, R.A.M., van Dijk, A.I.J.M., Liu, Y.Y., Renzullo, L.J., Dharssi, I., Parinussa, R.M., Can Der Schalie, R., Gevaert, A., Walker, J., McJannet, D., Cleverly, J., Haverd, V., Trudinger, C.M., Briggs, P.R., 2016. Comparison of remotely sensed and modelled soil moisture data sets across Australia. Remote Sens. Environ. 186, 479-500. https://doi.org/10.1016/j.rse.2016.09.015.

Horridge, M., Madden, J., Wittwer, G., 2005. The impact of the 2002-2003 drought on Australia. J. Policy Model. 27 (3), 285-308. https://doi.org/10.1016/j.jpolmod. 2005.01.008.

Johnston, R.M., Barry, S.J., Bleys, E., Bui, E.N., Moran, C.J., Simon, D.A.P., Carlile, P., McKenzie, N.J., Henderson, B.L., Chapman, G., Imhoff, M., Maschmedt, D., Howe, D., Grose, C., Schoknecht, N., Powell, B., Grundy, M., 2003. ASRIS: the database. Soil Res. 41 (6), 1021-1036. https://doi.org/10.1071/SR02033.

Jones, D.A., Wang, W., Fawcett, R., 2009. High-quality spatial climate data-sets for Australia. Aust. Meteorol. Oceanogr. J. 58 (4), 233.

Kerr, Y.H., Waldteufel, P., Wigneron, J.P., Delwart, S., Cabot, F., Boutin, J., Escorihuela, M.J., Font, J., Reul, N., Grihier, C., Juglea, S.E., Drinkwater, M.R., Hahne, A., MartinNeira, M., Mecklenburg, S., 2010. The SMOS mission: new tool for monitoring key elements of the global water cycle. Proc. IEEE 98 (5), 666-687. https://doi.org/10. 1109/JPROC.2010.2043032.

Keshavarz, M.R., Vazifedoust, M., Alizadeh, A., 2014. Drought monitoring using a Soil Wetness Deficit Index (SWDI) derived from MODIS satellite data. Agric. Water Manag. 132, 37-45. https://doi.org/10.1016/j.agwat.2013.10.004.

Kiem, A.S., Johnson, F., Westra, S., van Dijk, A., Evans, J.P., O'Donnell, A., Rouillard, A., Barr, C., Tyler, J., Thyer, M., Jakob, D., Woldemeskel, F., Sivakumar, B., Mehrotra, R., 2016. Natural hazards in Australia: droughts. Clim. Change 139 (1), 37-54. https://doi.org/10.1007/s10584-016-1798-7.

Kim, S., Liu, Y.Y., Johnson, F.M., Parinussa, R.M., Sharma, A., 2015. A global comparison of alternate AMSR2 soil moisture products: why do they differ? Remote Sens. Environ. 161, 43-62. https://doi.org/10.1016/j.rse.2015.02.002.

Kim, H., Zohaib, M., Cho, E., Kerr, Y.H., Choi, M., 2017. Development and assessment of the sand dust prediction model by utilizing microwave-based satellite soil moisture and reanalysis datasets in east asian desert areas. Adv. Meteorol 2017. https://doi. org $/ 10.1155 / 2017 / 1917372$

Kim, H., Parinussa, R., Konings, A., Wagner, W., Cosh, M., Lakshmi, V., Zohaib, M., Choi, M., 2018. Global-scale Assessment and combination of SMAP with ASCAT (active) and AMSR2 (passive) soil moisture products. Remote Sens. Environ. 204, 260-275. https://doi.org/10.1016/j.rse.2017.10.026.

Koster, R.D., Guo, Z., Yang, R., Dirmeyer, P.A., Mitchell, K., Puma, M.J., 2009. On the nature of soil moisture in land surface models. J. Clim. 22 (16), 4322-4335. https:// doi.org/10.1175/2009JCLI2832.1.

Łabędzki, L., 2007. Estimation of local drought frequency in central Poland using the tandardized precipitation index SPI. Irrig. Drain.: J. Int. Comm. Irrig. Drain. 56 (1) 67-77.

Lei, F., Crow, W.T., Shen, H., Parinussa, R.M., Holmes, T.R., 2015. The impact of local acquisition time on the accuracy of microwave surface soil moisture retrievals ove the contiguous United States. Rem. Sens. 7 (10), 13448-13465. https://doi.org/10. $3390 /$ rs71013448.

Martínez-Fernández, J., González-Zamora, A., Sánchez, N., Gumuzzio, A., 2015. A soil water based index as a suitable agricultural drought indicator. J. Hydrol. 522, 265-273. https://doi.org/10.1016/j.jhydrol.2014.12.051.

Martínez-Fernández, J., González-Zamora, A., Sánchez, N., Gumuzzio, A., HerreroJiménez, C.M., 2016. Satellite soil moisture for agricultural drought monitoring assessment of the SMOS derived Soil Water Deficit Index. Remote Sens. Environ. 177, 277-286. https://doi.org/10.1016/j.rse.2016.02.064.

Massari, C., Camici, S., Ciabatta, L., Brocca, L., 2018. Exploiting satellite-based surface soil moisture for flood forecasting in the Mediterranean area: state update versus rainfall correction. Rem. Sens. 10 (2), 292. https://doi.org/10.3390/rs10020292.
McKee, T.B., Doesken, N.J., Kleist, J., 1993. The relationship of drought frequency and duration to time scales. In: Proceedings of the 8th Conference on Applied Climatology. vol. 17. American Meteorological Society, Boston, MA, pp. 179-183. http://clima1.cptec.inpe.br/ rclima1/pdf/paper_spi.pdf 22 .

Mishra, A.K., Singh, V.P., 2010. A review of drought concepts. J. Hydrol. 391 (1), 202-216. https://doi.org/10.1016/j.jhydrol.2010.07.012.

Mishra, A., Vu, T., Veettil, A.V., Entekhabi, D., 2017. Drought monitoring with soil moisture active passive (SMAP) measurements. J. Hydrol. 552, 620-632. https://doi. org/10.1016/j.jhydrol.2017.07.033.

Mo, T., Choudhury, B.J., Schmugge, T.J., Wang, J.R., Jackson, T.J., 1982. A model for microwave emission from vegetation-covered fields. J. Geophys. Res.: Oceans 87 (C13), 11229-11237. https://doi.org/10.1029/JC087iC13p11229.

Mohammed, R., Scholz, M., 2017. Adaptation strategy to mitigate the impact of climate change on water resources in arid and semi-arid regions: a case study. Water Resour. Manag. 31 (11), 3557-3573.

Mozny, M., Trnka, M., Zalud, Z., Hlavinka, P., Nekovar, J., Potop, V., Virag, M., 2012. Use of a soil moisture network for drought monitoring in the Czech Republic. Theor. Appl. Climatol. 107 (1-2), 99-111. https://doi.org/10.1007/s00704-011-0460-6.

Nagler, P.L., Glenn, E.P., Kim, H., Emmerich, W., Scott, R.L., Huxman, T.E., Huete, A.R., 2007. Relationship between evapotranspiration and precipitation pulses in a semiarid rangeland estimated by moisture flux towers and MODIS vegetation indices. J. Arid Environ. 70 (3), 443-462.

Narasimhan, B., Srinivasan, R., 2005. Development and evaluation of soil moisture deficit index (SMDI) and evapotranspiration deficit index (ETDI) for agricultural drought monitoring. Agric. For. Meteorol. 133 (1), 69-88. https://doi.org/10.1016/j. agrformet.2005.07.012

Owe, M., de Jeu, R., Walker, J., 2001. A methodology for surface soil moisture and vegetation optical depth retrieval using the microwave polarization difference index. IEEE Trans. Geosci. Remote Sens. 39 (8), 1643-1654. https://doi.org/10.1109/36. 942542.

Palmer, W.C., 1965. Meteorological Drought, vol. 30 US Department of Commerce, Weather Bureau, Washington, DC.

Palmer, W.C., 1968. Keeping Track of Crop Moisture Conditions, Nationwide: the New Crop Moisture Index. https://doi.org/10.1080/00431672.1968.9932814.

Panu, U.S., Sharma, T.C., 2002. Challenges in drought research: some perspectives and future directions. Hydrol. Sci. J. 47 (S1), S19-S30. https://doi.org/10.1080/ 02626660209493019.

Parinussa, R.M., Holmes, T.R., Wanders, N., Dorigo, W.A., de Jeu, R.A., 2015. A preliminary study toward consistent soil moisture from AMSR2. J. Hydrometeorol. 16 (2), 932-947. https://doi.org/10.1175/JHM-D-13-0200.1.

Park, J., Baik, J., Choi, M., Jeong, J., Sur, C., 2019. Hydrological severity assessment of extreme climate conditions. Int. J. Climatol. https://doi.org/10.1002/joc.5984.

Peel, M.C., Finlayson, B.L., McMahon, T.A., 2007. Updated world map of the Köppen-Geiger climate classification. Hydrol. Earth Syst. Sci. 11, 1633-1644.

Penman, H.L., 1948. Natural evaporation from open water, bare soil and grass. In: Proceedings of the Royal Society of London. Series A, Mathematical and Physical Sciences, vol. 193. pp. 120-145 (1032).

Purcell, L.C., Sinclair, T.R., McNew, R.W., 2003. Drought avoidance assessment for summer annual crops using long-term weather data. Agron. J. 95 (6), 1566-1576 https://doi.org/10.2134/agronj2003.1566.

Qin, Y., Yang, D., Lei, H., Xu, K., Xu, X., 2015. Comparative analysis of drought based on precipitation and soil moisture indices in Haihe basin of North China during the period of 1960-2010. J. Hydrol. 526, 55-67. https://doi.org/10.1016/j.jhydrol 2014.09.068.

Rahmat, S.N., Jayasuriya, N., Bhuiyan, M., 2015. Assessing droughts using meteorological drought indices in Victoria, Australia. Hydrol. Res. 46 (3), 463-476.

Reichle, R.H., Koster, R.D., 2005. Global assimilation of satellite surface soil moisture retrievals into the NASA Catchment land surface model. Geophys. Res. Lett. 32 (2). https://doi.org/10.1029/2004GL021700.

Reichle, R.H., Crow, W.T., Keppenne, C.L., 2008. An adaptive ensemble Kalman filter for soil moisture data assimilation. Water Resour. Res. 44 (3). https://doi.org/10.1029/ 2007WR006357.

Renzullo, L.J., Van Dijk, A.I.J.M., Perraud, J.M., Collins, D., Henderson, B., Jin, H., Smith, A.B., McJannet, D.L., 2014. Continental satellite soil moisture data assimilation improves root-zone moisture analysis for water resources assessment. J. Hydrol. 519, 2747-2762. https://doi.org/10.1016/j.jhydrol.2014.08.008.

Rhee, J., Im, J., Carbone, G.J., 2010. Monitoring agricultural drought for arid and humid regions using multi-sensor remote sensing data. Remote Sens. Environ. 114 (12), 2875-2887. https://doi.org/10.1016/j.rse.2010.07.005.

Rodell, M., Houser, P.R., Jambor, U.E.A., Gottschalck, J., Mitchell, K., Meng, C.J., Arsenault, K., Cosgrove, B., Radakovich, J., Bosilovich, M., Entin, J.K., Walker, J.P., Lohmann, D., Toll, D., 2004. The global land data assimilation system. Bull. Am. Meteorol. Soc. 85 (3), 381-394. 75-2887. https://doi.org/10.1016/j.rse.2010.07. 005.

Rowell, D.P., Folland, C.K., Maskell, K., Ward, M.N., 1995. Variability of summer rainfall over tropical North Africa (1906-92): observations and modelling. Q. J. R. Meteorol. Soc. 121 (523), 669-704. https://doi.org/10.1002/qj.49712152311.

Saxton, K.E., Rawls, W., Romberger, J.S., Papendick, R.I., 1986. Estimating generalized soil-water characteristics from texture. Soil Sci. Soc. Am. J. 50 (4), 1031-1036. https://doi.org/10.2136/sssaj1986.03615995005000040039x.

Sánchez, N., González-Zamora, Á., Martínez-Fernández, J., Piles, M., Pablos, M., 2018. Integrated remote sensing approach to global agricultural drought monitoring. Agric. For. Meteorol. 259, 141-153.

Scipal, K., Holmes, T., de Jeu, R., Naeimi, V., Wagner, W., 2008. A possible solution for the problem of estimating the error structure of global soil moisture data sets. Geophys. Res. Lett. 35, L24403. https://doi.org/10.1029/2008gl035599. 
Seneviratne, S.I., Koster, R.D., Guo, Z., Dirmeyer, P.A., Kowalczyk, E., Lawrence, D., Liu, P., Lu, C.H., Mocko, D., Oleson, K.W., Verseghy, D., 2006. Soil moisture memory in AGCM simulations: analysis of global land-atmosphere coupling experiment (GLACE) data. J. Hydrometeorol. 7 (5), 1090-1112.

Su, C.H., Ryu, D., Young, R.I., Western, A.W., Wagner, W., 2013. Inter-comparison of microwave satellite soil moisture retrievals over the Murrumbidgee Basin, southeast Australia. Remote Sens. Environ. 134, 1-11. https://doi.org/10.1016/j.rse.2013.02. 016.

Tigkas, D., Vangelis, H., Tsakiris, G., 2017. An enhanced effective reconnaissance drought index for the characterisation of agricultural drought. Environ. Process. 4 (1), 137-148.

Tsakiris, G., Vangelis, H., 2005. Establishing a drought index incorporating evapotranspiration. Eur. Water 9 (10), 3-11.

Thomas, T., Jaiswal, R.K., Galkate, R.V., Nayak, T.R., 2016. Reconnaissance drought index based evaluation of meteorological drought characteristics in Bundelkhand. Procedia Technology 24, 23-30.

Torres, G.M., Lollato, R.P., Ochsner, T.E., 2013. Comparison of drought probability assessments based on atmospheric water deficit and soil water deficit. Agron. J. 105 (2), 428-436. https://doi.org/10.2134/agronj2012.0295.

Tregoning, P., McClusky, S., Van Dijk, A.I.J.M., Crosbie, R.S., Peña-Arancibia, J.L., 2012. Assessment of GRACE Satellites for Groundwater Estimation in Australia. National Water Commission, Canberra, pp. 82.

Tsakiris, G., Pangalou, D., Vangelis, H., 2007. Regional drought assessment based on the reconnaissance drought index (RDI). Water Resour. Manag. 21 (5), 821-833.

Ulaby, F.T., Batlivala, P.P., Dobson, M.C., 1978. Microwave backscatter dependence on surface roughness, soil moisture, and soil texture: Part I-bare soil. IEEE Trans. Geosci. Electron. 16 (4), 286-295. https://doi.org/10.1109/TGE.1978.294586.

Van Dijk, A.I.J.M., Bruijnzeel, L.A., 2001. Modelling rainfall interception by vegetation of variable density using an adapted analytical model. Part 1 . Model description. J. Hydrol. 247 (3), 230-238. https://doi.org/10.1016/S0022-1694(01)00392-4.

van Dijk, A.I., Beck, H.E., Crosbie, R.S., de Jeu, R.A., Liu, Y.Y., Podger, G.M., Timbal, B., Viney, N.R, 2013. The Millennium Drought in southeast Australia (2001-2009): natural and human causes and implications for water resources, ecosystems, economy, and society. Water Resour. Res. 49 (2), 1040-1057.

Vaze, J., Viney, N., Stenson, M., Renzullo, L., Van Dijk, A., Dutta, D., Crosbie, R., Lerat, J., Penton, D., Vleeshouwer, J., Peeters, L., Teng, J., Kim, S., Hughes, J., Dawes, W., Zhang, Y., Leighton, B., Perraud, J.-M., Joehnk, K., Yang, A., Wang, B., Frost, A.,
Elmahdi, A., Smith, A., Daamen, C., 2013. The Australian water resource assessment modelling system (AWRA). In: 20th International Congress on Modelling and Simulation, vol. 16 Adelaide, Australia.

Verhoest, N.E., Lievens, H., Wagner, W., Álvarez-Mozos, J., Moran, M.S., Mattia, F., 2008. On the soil roughness parameterization problem in soil moisture retrieval of bare surfaces from synthetic aperture radar. Sensors 8 (7), 4213-4248. https://doi.org/10. 3390/s8074213.

Vicente-Serrano, S.M., Beguería, S., Lorenzo-Lacruz, J., Camarero, J.J., López-Moreno, J.I., Azorin-Molina, C., Revuelto, J., Morán-Tejeda, E., Sanchez-Lorenzo, A., 2012. Performance of drought indices for ecological, agricultural, and hydrological applications. Earth Interact. 16 (10), 1-27.

Viney, N., Vaze, J., Crosbie, R., Wang, B., Dawes, W., Frost, A., 2014. AWRA-L V4. 5: Technical Description of Model Algorithms and Inputs. https://doi.org/10.4225/08/ $58542 \mathrm{e} 0 \mathrm{f} 24569$.

Wagner, W., Dorigo, W., de Jeu, R., Fernandez, D., Benveniste, J., Haas, E., Ertl, M., 2012 Fusion of active and passive microwave observations to create an essential climate variable data record on soil moisture. ISPRS Annals of the Photogrammetry, Remote Sensing and Spatial Information Sciences (ISPRS Annals) 7, 315-321.

Wagner, W., Hahn, S., Kidd, R., Melzer, T., Bartalis, Z., Hasenauer, S., Figa-Saldaña, J., de Rosnay, P., Jann, A., Schneider, S., Komma, J., Kubu, G., Brugger, K., Aubrecht, C., Züger, J., Gangkofner, U., Kienberger, S., Brocca, L., Wang, Y., Blöschl, G., Eitzinger, J., Steinnocher, K., Zeil, P., Rubel, F., 2013. The ASCAT soil moisture product: a review of its specifications, validation results, and emerging applications. Meteorol. Z. 22 (1), 5-33. https://doi.org/10.1127/0941-2948/2013/0399.

Woli, P., Jones, J.W., Ingram, K.T., Fraisse, C.W., 2012. Agricultural reference index for drought (ARID). Agron. J. 104 (2), 287-300. https://doi.org/10.2134/agronj2011. 0286.

Wu, Q., Liu, H., Wang, L., Deng, C., 2016. Evaluation of AMSR2 soil moisture products over the contiguous United States using in situ data from the International Soil Moisture Network. Int. J. Appl. Earth Obs. Geoinf. 45, 187-199. https://doi.org/10. 1016/j.jag.2015.10.011.

Yilmaz, M.T., Crow, W.T., 2013. The optimality of potential rescaling approaches in land data assimilation. J. Hydrometeorol. 14 (2), 650-660. https://doi.org/10.1175/JHMD-12-052.1.

Zohaib, M., Kim, H., Choi, M., 2017. Evaluating the patterns of spatiotemporal trends of root zone soil moisture in major climate regions in east Asia. J. Geophys. Res.: Atmosphere 122 (15), 7705-7722. https://doi.org/10.1002/2016JD026379. 